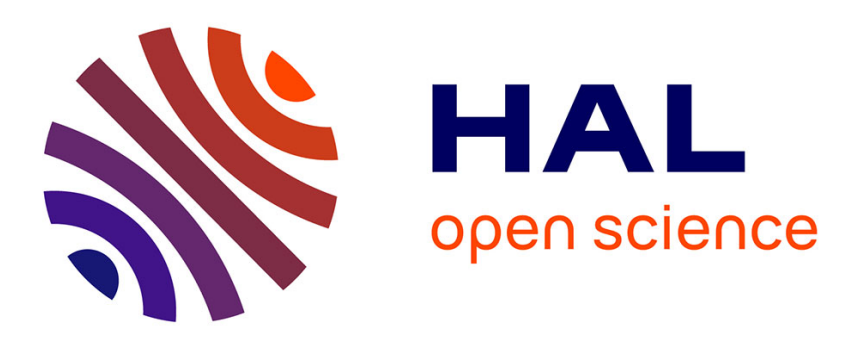

\title{
Synthesis, Crystal Structure, and Characterization of Two Novel One- and Two-Dimensionally Polymeric Copper(II) Phosphonoacetates
}

\author{
Roberto Köferstein, Michael Arnold, Christian Robl
}

\section{To cite this version:}

Roberto Köferstein, Michael Arnold, Christian Robl. Synthesis, Crystal Structure, and Characterization of Two Novel One- and Two-Dimensionally Polymeric Copper(II) Phosphonoacetates. Journal of Inorganic and General Chemistry / Zeitschrift für anorganische und allgemeine Chemie, 2017, Z. Anorg. Allg. Chem., 643 (3), pp.276-285. 10.1002/zaac.201600457 . hal-01986788

\section{HAL Id: hal-01986788 \\ https://hal.science/hal-01986788}

Submitted on 30 Jan 2019

HAL is a multi-disciplinary open access archive for the deposit and dissemination of scientific research documents, whether they are published or not. The documents may come from teaching and research institutions in France or abroad, or from public or private research centers.
L'archive ouverte pluridisciplinaire HAL, est destinée au dépôt et à la diffusion de documents scientifiques de niveau recherche, publiés ou non, émanant des établissements d'enseignement et de recherche français ou étrangers, des laboratoires publics ou privés. 
Journal of Inorganic and General Chemistry

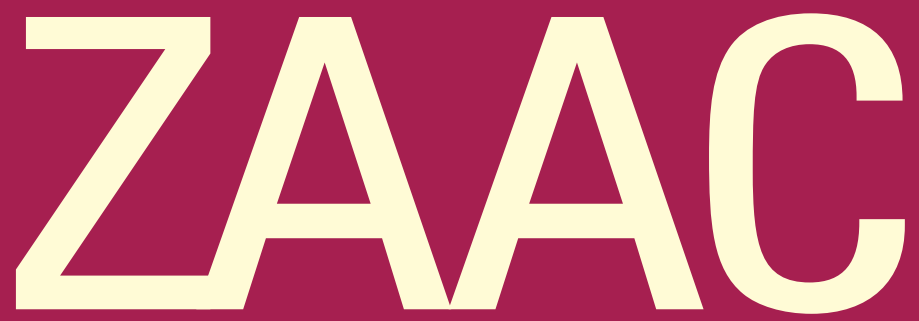

Zeitschrift für anorganische und allgemeine Chemie

\section{7}

\section{$643 / 3$}

$$
\frac{80{ }^{\circ} \mathrm{C}}{\text { urea }} \mathrm{Cu}^{2+}+\text { phosphonoacetic acid } \frac{\mathrm{RT}}{\mathrm{pH} \approx 3}
$$

\section{Layers}

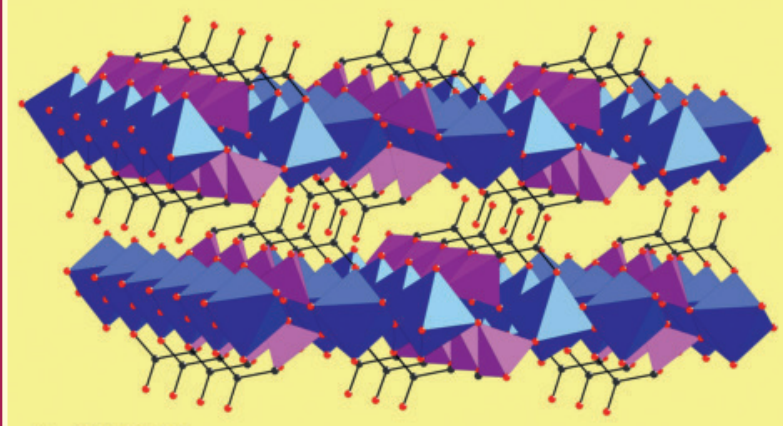

Cu P O

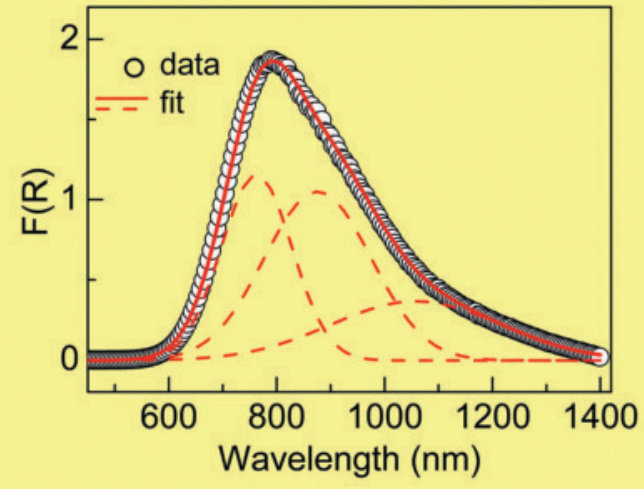

Polyanionic Chains
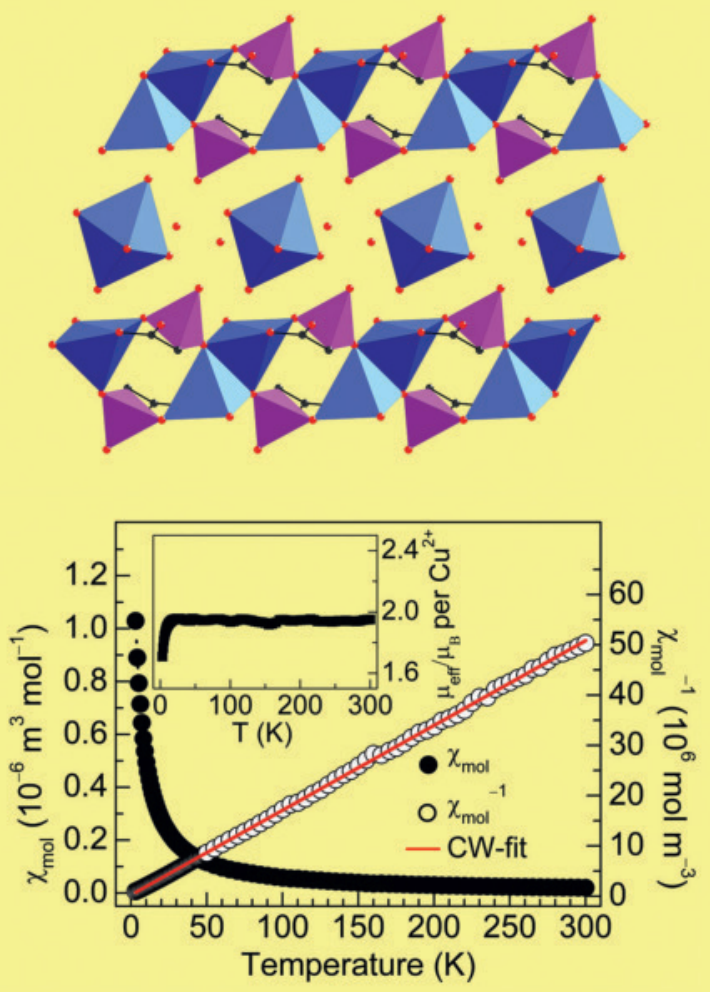

Cover Picture: Synthesis, Crystal Structure, and Characterization

of Two Novel One- and Two-Dimensionally Polymeric

Copper(II) Phosphonoacetates

Roberto Köferstein, Michael Arnold, and Christian Robl 


\title{
Z. Anorg. Allg. Chem. 643 (2017) 276-285. DOI: 10.1002/zaac.201600457
}

\section{Synthesis, Crystal Structure and Characterization of Two Novel One- and Two-Dimensionally Polymeric Copper(II) Phosphonoacetates}

\author{
Roberto Köferstein $^{[\mathrm{b}]}$, Michael Arnold ${ }^{[\mathrm{a}]}$, and Christian Robl ${ }^{[\mathrm{a}]}$ \\ [a] Institute of Inorganic and Analytical Chemistry, Friedrich-Schiller-University Jena, Humboldtstrasse 8, 07743 Jena, Germany \\ [b] Institute of Chemistry, Inorganic Chemistry, Martin Luther University Halle-Wittenberg, Kurt-Mothes-Strasse 2, 06120 Halle, \\ Germany
}

\begin{abstract}
Blue single crystals of $\mathrm{Cu}\left[\mu_{2}-\mathrm{OOC}\left(\mathrm{CH}_{2}\right) \mathrm{PO}_{3} \mathrm{H}\right] \cdot 2 \mathrm{H}_{2} \mathrm{O}(\mathbf{1})$ and $\mathrm{Cu}_{1.5}\left[\mu_{3}-\mathrm{OOC}\left(\mathrm{CH}_{2}\right) \mathrm{PO}_{3}\right] \cdot 5 \mathrm{H}_{2} \mathrm{O}(2)$ have been prepared in aqueous solution. 1: Space group C2/c (no. 15) with $a=1623.3(2), b=624.0(1), c=1495.5(2)$ $\mathrm{pm}, \beta=122.45(1)^{\circ}$. $\mathrm{Cu}$ is coordinated by three oxygen atoms stemming from the hydrogenphosphonoacetate dianion and three water molecules to form a distorted octahedron. The $\mathrm{Cu}-\mathrm{O}$ bonds range from 190.4(3) to 278.5(3) $\mathrm{pm}$. The connection between the $\mathrm{Cu}^{2+}$ cations and the hydrogenphosphonoacetate dianions leads to a two-dimensional structure with layers parallel to ( $\overline{101}$ ). The layers are linked by hydrogen bonds. 2: Space group $P \overline{1}$ (no. 2) with $a=608.2(1), b=800.1(1), c=1083.6(1) \mathrm{pm}, \alpha=94.98(1)^{\circ}, \beta=105.71(1)^{\circ}, \gamma=109.84(1)^{\circ}$. There are two crystallographically independent $\mathrm{Cu}^{2+}$ cations coordinated in a square pyramidal and an octahedral fashion, respectively. The $\mathrm{Cu}-\mathrm{O}$ bonds range from 192.9(2) to 237.2(2) $\mathrm{pm}$. The coordination of the phosphonoacetate trianion to $\mathrm{Cu}(1)$ results in infinite polyanionic chains parallel to [100] with a composition of $\left\{\mathrm{Cu}\left(\mathrm{H}_{2} \mathrm{O}\right)\left[\mathrm{OOC}\left(\mathrm{CH}_{2}\right) \mathrm{PO}_{3}\right]\right\}_{n}{ }^{n-}$. Hydrated $\mathrm{Cu}(2)$ cations are accommodated between the chains as counter ions. $\mathbf{1}$ and 2 show structural features of cation exchangers. Magnetic measurements reveal a paramagnetic Curie-Weiss behaviour. Compound 2 shows antiferromagnetic coupling between $\mathrm{Cu}^{2+}$ ions due to a super-superexchange coupling. The UV/Vis spectra of 1 suggests three $d-d$ transition bands at $763 \mathrm{~nm}\left({ }^{2} B_{1} \rightarrow{ }^{2} E\right), 878 \mathrm{~nm}\left({ }^{2} B_{1} \rightarrow\right.$ $\left.{ }^{2} \mathrm{~B}_{2}\right)$, and $1061 \mathrm{~nm}\left({ }^{2} \mathrm{~B}_{1} \rightarrow{ }^{2} \mathrm{~A}_{1}\right)$. Thermoanalytical investigations in air show that compound $\mathbf{1}$ is stable up to 165 ${ }^{\circ} \mathrm{C}$, whereas the decomposition of 2 begins at $63{ }^{\circ} \mathrm{C}$.
\end{abstract}

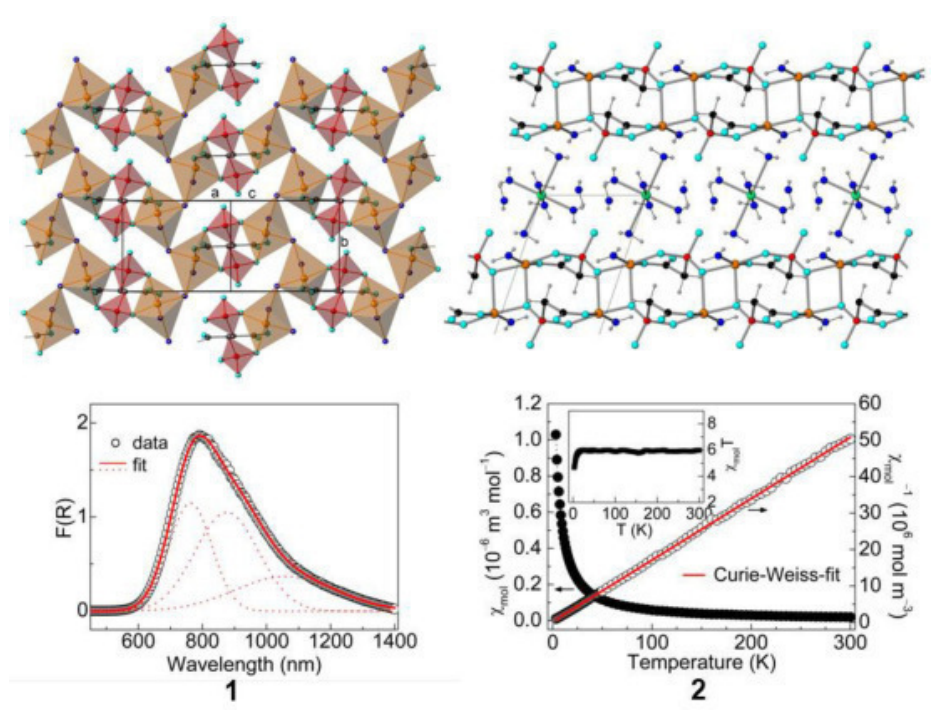




\title{
Synthesis, Crystal Structure and Characterization of Two Novel One- and Two-Dimensionally Polymeric Copper(II) Phosphonoacetates
}

\author{
Roberto Köferstein $^{[\mathrm{b}]}$, Michael Arnold ${ }^{[\mathrm{a}]}$, and Christian Robl${ }^{\star[a]}$
}

Dedicated to Prof. Dr. Wolfgang Beck on the occasion of his 85th birthday.

\begin{abstract}
Blue single crystals of $\mathrm{Cu}\left[\mu_{2}-\mathrm{OOC}\left(\mathrm{CH}_{2}\right) \mathrm{PO}_{3} \mathrm{H}\right] \cdot 2 \mathrm{H}_{2} \mathrm{O}$ (1) and $\mathrm{Cu}_{1.5}\left[\mu_{3}-\mathrm{OOC}\left(\mathrm{CH}_{2}\right) \mathrm{PO}_{3}\right] \cdot 5 \mathrm{H}_{2} \mathrm{O}$ (2) have been prepared in aqueous solution. 1: Space group C2/c (no. 15) with $a=1623.3(2), b$ $=624.0(1), c=1495.5(2) \mathrm{pm}, \beta=122.45(1)^{\circ}$. Cu is coordinated by three oxygen atoms stemming from the hydrogenphosphonoacetate dianion and three water molecules to form a distorted octahedron. The $\mathrm{Cu}-\mathrm{O}$ bonds range from $190.4(3)$ to $278.5(3) \mathrm{pm}$. The connection between the $\mathrm{Cu}^{2+}$ cations and the hydrogenphosphonoacetate dianions leads to a two-dimensional structure with layers parallel to ( $\overline{1} 01)$. The layers are linked by hydrogen bonds. 2: Space group $P \overline{1}$ (no. 2) with $a=608.2(1), b=$ 800.1(1), $c=1083.6(1) \mathrm{pm}, \alpha=94.98(1)^{\circ}, \beta=105.71(1)^{\circ}, \gamma=$ $109.84(1)^{\circ}$. There are two crystallographically independent $\mathrm{Cu}^{2+}$ cations coordinated in a square pyramidal and an octahedral fashion, respectively. The $\mathrm{Cu}-\mathrm{O}$ bonds range from 192.9(2) to 237.2(2) pm. The coordination of the phosphonoacetate trianion to $\mathrm{Cu}(1)$ results in infinite polyanionic chains parallel to [100] with a composition of $\left\{\mathrm{Cu}\left(\mathrm{H}_{2} \mathrm{O}\right)\left[\mathrm{OOC}\left(\mathrm{CH}_{2}\right) \mathrm{PO}_{3}\right]\right\}_{n}{ }^{n-}$. Hydrated $\mathrm{Cu}(2)$ cations are accommodated between the chains as counter ions. $\mathbf{1}$ and $\mathbf{2}$ show structural features of cation exchangers. Magnetic measurements reveal a paramagnetic Curie-Weiss behaviour. Compound 2 shows antiferromagnetic coupling between $\mathrm{Cu}^{2+}$ ions due to a supersuperexchange coupling. The UV/Vis spectra of 1 suggests three $\mathrm{d}-\mathrm{d}$ transition bands at $763 \mathrm{~nm}\left({ }^{2} \mathrm{~B}_{1} \rightarrow{ }^{2} \mathrm{E}\right), 878 \mathrm{~nm}\left({ }^{2} \mathrm{~B}_{1} \rightarrow{ }^{2} \mathrm{~B}_{2}\right)$, and $1061 \mathrm{~nm}\left({ }^{2} \mathrm{~B}_{1} \rightarrow{ }^{2} \mathrm{~A}_{1}\right)$. Thermoanalytical investigations in air show that compound 1 is stable up to $165^{\circ} \mathrm{C}$, whereas the decomposition of 2 begins at $63^{\circ} \mathrm{C}$.
\end{abstract}

\section{Introduction}

Metal organophosphonates are of great interest due to their potential application e.g. as gas-phase sensor ${ }^{[1]}$, catalyst ${ }^{[2,3]}$, and ion exchanger ${ }^{[4]}$. Using bifunctional organophosphonates, e.g.

Prof. Dr. C. Robl

Fax: +49-3641-948152

E-mail: crr@uni-jena.de

[a] Institute of Inorganic and Analytical Chemistry

Friedrich-Schiller-University Jena

Humboldtstrasse 8, 07743 Jena, Germany

[b] Institute of Chemistry, Inorganic Chemistry

Martin Luther University Halle-Wittenberg

Kurt-Mothes-Strasse 2

06120 Halle, Germany diphosphonate or phosphonocarboxylate units as ligands, various structural motives can be made possible. ${ }^{[5-14]}$ Zinc 5phosphonobenzene-1,3-dicarboxylate can be used as catalyst in Friedel-Crafts benzylation reactions and cobalt uranyl phosphonoacetate shows selective $\mathrm{CO}_{2}$ uptake. ${ }^{[15-17]}$ One of the simplest phosphonocarboxylic acids is phosphonoacetic acid. The deprotonation of the phosphonoacetic acid can lead to the monoanionic, dianionic, and trianionic form, respectively. ${ }^{[18]}$ The three forms of the phosphonoacetate anion appear in e.g. $M\left[\mathrm{HOOC}\left(\mathrm{CH}_{2}\right) \mathrm{PO}_{3} \mathrm{H}_{2} \cdot 2 \mathrm{H}_{2} \mathrm{O} \quad(M=\mathrm{Mn}, \mathrm{Co}, \mathrm{Zn}, \mathrm{Cu})^{[19]}\right.$, $\mathrm{UO}_{2}\left[\mathrm{HOOC}\left(\mathrm{CH}_{2}\right) \mathrm{PO}_{3}\right]^{[20]}, \mathrm{Cu}_{2}\left[\mathrm{OOC}\left(\mathrm{CH}_{2}\right) \mathrm{PO}_{3} \mathrm{H}_{2}(\mathrm{bpy})_{2}{ }^{[21]}\right.$, and $\mathrm{Mn}_{3}\left[\mathrm{OOC}\left(\mathrm{CH}_{2}\right) \mathrm{PO}_{3}\right]_{2}^{[22]}$. The connection between $\mathrm{Cu}^{2+}$ and phosphonoacetate anions leads to coordination polymers with one-, two and three-dimensional structural features. ${ }^{[19,23,24]}$ The obtained structures depend on the reaction temperature, Cu:P ratio, $\mathrm{pH}$ value, and the deprotonation stage of the phosphonoacetate anion. The structures of $\mathrm{Cu}$ (II) phosphonoacetates can be modified using additional $\mathrm{N}$-donor ligands. ${ }^{[21]}$

Herein, we report on a novel two-dimensionally polymeric copper(II) hydrogenphosphonoacetate dihydrate and a onedimensionally polymeric copper(II) phosphonoacetate pentahydrate.

\section{Results and Discussion}

\section{$\mathrm{Cu}\left[\mathrm{\mu}_{2}-\mathrm{OOC}\left(\mathrm{CH}_{2}\right) \mathrm{PO}_{3} \mathrm{H}\right] \cdot 2 \mathrm{H}_{2} \mathrm{O}(1)$}

In $\mathrm{Cu}\left[\mu_{2}-\mathrm{OOC}\left(\mathrm{CH}_{2}\right) \mathrm{PO}_{3} \mathrm{H}\right] \cdot 2 \mathrm{H}_{2} \mathrm{O}$ (1) the $\mathrm{Cu}^{2+}$ cations occupy the general position of space group $\mathrm{C} 2 / \mathrm{c}$. The $\mathrm{Cu}$ cations are sixfold coordinated $(4+1+1)$ in a distorted octahedral fashion (Figure 1). The equatorial positions are occupied by the carboxylate oxygen atom $\mathrm{O}(1)$, the phosphonate oxygen atom $\mathrm{O}(3)$ stemming from the same hydrogenphosphonoacetate dianion, and two water molecules $[\mathrm{O}(\mathrm{w} 1), \mathrm{O}(\mathrm{w} 2)]$. The $\mathrm{Cu}-\mathrm{O}$ distances in the equatorial plane range from 190.4(3) to 200.4(4) $\mathrm{pm}$ (Table 1). The best least-square-plane through $\mathrm{Cu}, \mathrm{O}(1)$, $\mathrm{O}(3), \mathrm{O}(\mathrm{w} 1)$, and $\mathrm{O}(\mathrm{w} 2)$ shows a significant deviation from planarity (maximum deviation $24.0 \mathrm{pm}$ ). The axial positions are occupied by the phosphonate oxygen atom $\mathrm{O}(4)$, from a second, but crystallographically equivalent hydrogenphosphonoacetate dianion and the water molecule $\mathrm{O}\left(\mathrm{w} 2^{\prime}\right)^{\# 2}$ with longer bond lengths of 229.5(3) and 278.5(3) pm, respectively. According to Hathaway ${ }^{[25,26]}$ and Pasquarello et al. ${ }^{[27]} \mathrm{Cu}-\mathrm{O}$ distances up to $300 \mathrm{pm}$ (sum of van der Waals radii) should be considered to be bonds. Such long $\mathrm{Cu}-\mathrm{O}$ bonds were also found in e.g. copper(II) 
malonates $^{[28]}$, copper(II) oxalatodiethylenetriamine ${ }^{[29]}$, galactose oxidase $^{[30]}$, and copper(II) bis(L-amino acid) complexes. ${ }^{[31,32]}$ The $\mathrm{O}-\mathrm{Cu}-\mathrm{O}$ angles differ considerably in part from the ideal values of $90^{\circ}$ and $180^{\circ}$, respectively. The $\mathrm{Cu}^{2+}$ coordination polyhedron can be approximately described with a $\mathrm{C}_{4 \mathrm{v}}$ point group symmetry. Employing the method of Brese and $\mathrm{O}^{\prime} \mathrm{Keeffe}^{[33]}$ the bond order is calculated to 2.10. Neighbouring $\mathrm{Cu}^{2+}$ coordination polyhedra are tilted against each other and linked by a common corner [O(w2)] which leads to infinite ribbons of copper polyhedra along [010] (Figure 2).

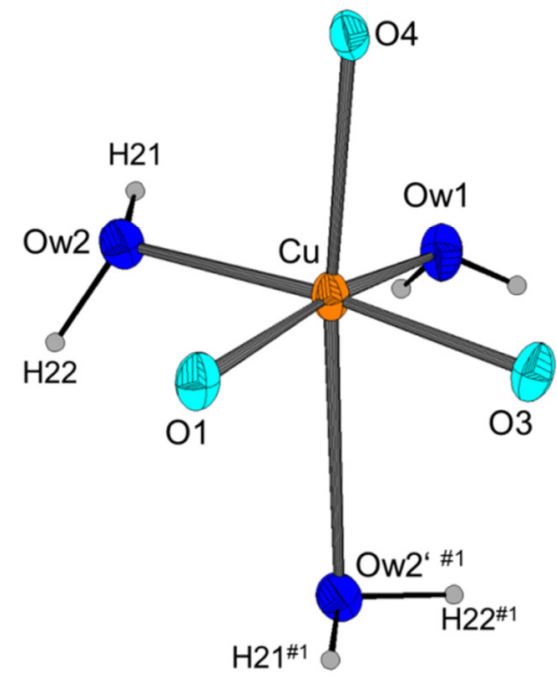

Figure 1. The coordination environment of $\mathrm{Cu}^{2+}$ in $\mathrm{Cu}\left[\mu_{2-}\right.$ OOC $\left.\left(\mathrm{CH}_{2}\right) \mathrm{PO}_{3} \mathrm{H}\right] \cdot 2 \mathrm{H}_{2} \mathrm{O}$ (1). Ellipsoids are given at $50 \%$ probability, arbitrary radii for hydrogen atoms. The index (') indicates the longest $\mathrm{Cu}-\mathrm{O}$ bond. Symmetry codes as in Table 1.

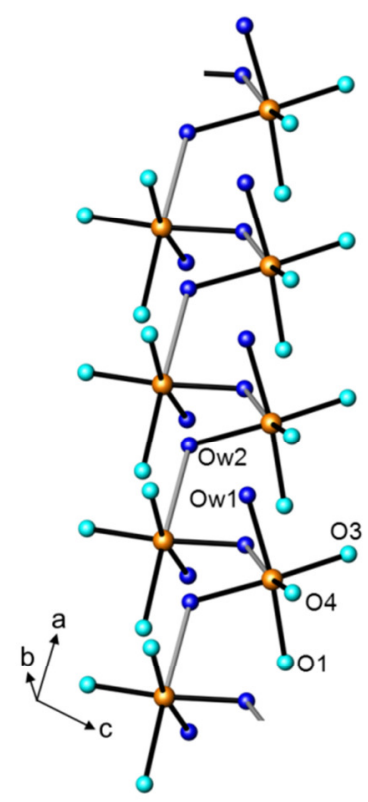

(a)

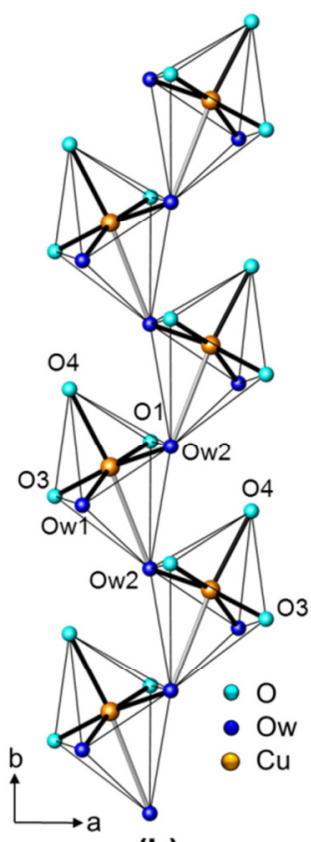

(b)
Figure 2. The connection of the $\mathrm{Cu}^{2+}$ polyhedra to infinite ribbons in 1. (a) view to (010), (b) view along [001]. The longest $\mathrm{Cu}-\mathrm{O}(\mathrm{w} 2)$ bond is drawn with a light grey bond. Hydrogen atoms are omitted for clarity.

Table 1. The coordination of $\mathrm{Cu}^{2+}$ in $\mathrm{Cu}\left[\mu_{2}-\mathrm{OOC}\left(\mathrm{CH}_{2}\right) \mathrm{PO}_{3} \mathrm{H}\right] \cdot 2 \mathrm{H}_{2} \mathrm{O}$ (1)

\begin{tabular}{llll}
\hline Distances (pm) & & & \\
\hline $\mathrm{Cu}-\mathrm{O}(1)$ & $198.6(3)$ & $\mathrm{Cu}-\mathrm{O}(\mathrm{w} 1)$ & $200.4(4)$ \\
$\mathrm{Cu}-\mathrm{O}(3)$ & $190.4(3)$ & $\mathrm{Cu}-\mathrm{O}(\mathrm{w} 2)$ & $195.9(3)$ \\
$\mathrm{Cu}-\mathrm{O}(4)^{\# 1}$ & $229.5(3)$ & $\mathrm{Cu}-\mathrm{O}\left(\mathrm{w} 2^{\prime}\right)^{\# 2}$ & $278.5(3)$ \\
\hline $\mathrm{Bond}$ angles ( $\left.{ }^{\circ}\right)$ & & & \\
\hline $\mathrm{O}(3)-\mathrm{Cu}-\mathrm{O}(\mathrm{w} 2)$ & $172.71(14)$ & $\mathrm{O}(3)-\mathrm{Cu}-\mathrm{O}\left(\mathrm{w} 2^{\prime}\right)^{\# 2}$ & $82.15(11)$ \\
$\mathrm{O}(\mathrm{w} 2)-\mathrm{Cu}-\mathrm{O}(1)$ & $86.33(13)$ & $\mathrm{O}(\mathrm{w} 1)-\mathrm{Cu}-\mathrm{O}\left(\mathrm{w}^{\prime}\right)^{\# 2}$ & $74.93(13)$ \\
$\mathrm{O}(\mathrm{w} 2)-\mathrm{Cu}-\mathrm{O}(\mathrm{w} 1)$ & $88.32(14)$ & $\mathrm{O}(\mathrm{w} 2)-\mathrm{Cu}-\mathrm{O}(4)^{\# 1}$ & $90.59(13)$ \\
$\mathrm{O}(3)-\mathrm{Cu}-\mathrm{O}(4)^{\# 1}$ & $96.52(12)$ & $\mathrm{O}(\mathrm{w} 1)-\mathrm{Cu}-\mathrm{O}(4)^{\# 1}$ & $96.29(13)$ \\
$\mathrm{O}(1)-\mathrm{Cu}-\mathrm{O}(4)^{\# 1}$ & $95.44(12)$ & $\mathrm{O}(\mathrm{w} 2)-\mathrm{Cu}-\mathrm{O}\left(\mathrm{w}^{\prime}\right)^{\# 2}$ & $90.57(11)$ \\
$\mathrm{O}(3)-\mathrm{Cu}-\mathrm{O}(1)$ & $94.58(13)$ & $\mathrm{O}(1)-\mathrm{Cu}-\mathrm{O}\left(\mathrm{w} 2^{\prime}\right)^{\# 2}$ & $93.42(11)$ \\
$\mathrm{O}(3)-\mathrm{Cu}-\mathrm{O}(\mathrm{w} 1)$ & $89.29(14)$ & $\mathrm{O}(4)-\mathrm{Cu}-\mathrm{O}\left(\mathrm{w} 2^{\prime}\right)^{\# 2}$ & $171.11(11)$ \\
$\mathrm{O}(1)-\mathrm{Cu}-\mathrm{O}(\mathrm{w} 1)$ & $167.14(14)$ & $\mathrm{Cu}-\mathrm{O}(\mathrm{w} 2)^{\# 2}-\mathrm{Cu}{ }^{\# 2}$ & $119.79(13)$ \\
\hline
\end{tabular}

Symmetry codes: The index (') indicates the longest $\mathrm{Cu}-\mathrm{O}$ bond. \#1: $-\mathrm{x},-\mathrm{y}+1,-$ z; \#2: 0.5-x, 0.5+y, 0.5-z

The carboxylate group in the hydrogenphosphonoacetate dianion is deprotonated. The $\mathrm{C}-\mathrm{O}$ bond lengths are between 
those typical for a double and a single bond. The bond to $\mathrm{O}(1)$ is significant longer than to $\mathrm{O}(2)$ obviously due to the coordination to $\mathrm{Cu}^{2+}$. The carboxylate group is twisted against the plane through $\mathrm{P}-\mathrm{C}(2)-\mathrm{C}(1)$ by $50.7(4)^{\circ}$. The phosphorous atom is surrounded by three oxygen atoms and one carbon atom from the ethylene group in a distorted tetrahedral manner (Figure 3 ). The $\mathrm{P}-\mathrm{O}$ bonds range from $149.3(3)$ to $157.7(3) \mathrm{pm}$, whereas the $\mathrm{P}-\mathrm{C}$ bond is $180.1(5) \mathrm{pm}$. The phosphonate oxygen atoms $\mathrm{O}(3)$ and $\mathrm{O}(4)$, bound to $\mathrm{Cu}^{2+}$ form the shortest $\mathrm{P}-\mathrm{O}$ bonds, whereas the protonated oxygen atom $\mathrm{O}(5)$ forms the longest one. The angles within the $\left[\mathrm{O}_{3} \mathrm{PC}\right]$ tetrahedron differ markedly from the ideal values (Table 2). Each hydrogenphosphonoacetate dianion connects two copper ions and adopts a $\mu_{2}$ coordination mode. Both the phosphonate- and the carboxylate group coordinate in a monodentate manner.

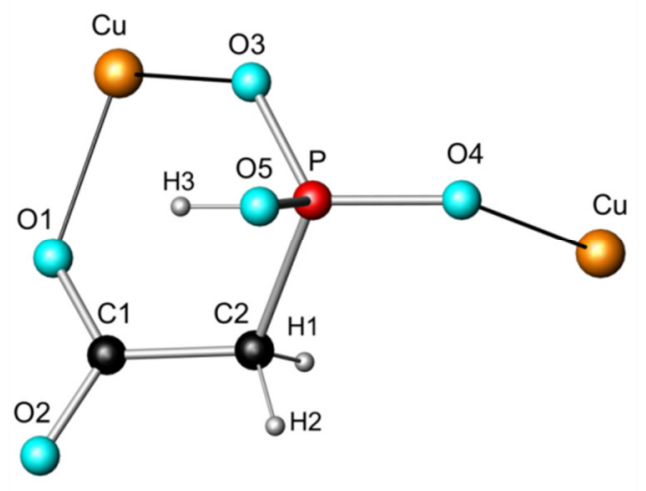

Figure 3. The connection between the hydrogenphosphonoacetate dianion and the $\mathrm{Cu}^{2+}$ cations in $\mathrm{Cu}\left[\mu_{2}-\mathrm{OOC}\left(\mathrm{CH}_{2}\right) \mathrm{PO}_{3} \mathrm{H}\right] \cdot 2 \mathrm{H}_{2} \mathrm{O}(1)$.

Table 2. Bond lengths and angles of the hydrogenphosphonoacetate dianion in $\mathrm{Cu}\left[\mathrm{\mu}_{2}-\mathrm{OOC}\left(\mathrm{CH}_{2}\right) \mathrm{PO}_{3} \mathrm{H}\right] \cdot 2 \mathrm{H}_{2} \mathrm{O}(1)$

\begin{tabular}{llll}
\hline Distances $(\mathrm{pm})$ & & \\
\hline $\mathrm{P}-\mathrm{O}(3)$ & $151.0(3)$ & $\mathrm{O}(1)-\mathrm{C}(1)$ & $128.3(5)$ \\
$\mathrm{P}-\mathrm{O}(4)$ & $149.3(3)$ & $\mathrm{O}(2)-\mathrm{C}(1)$ & $125.2(5)$ \\
$\mathrm{P}-\mathrm{O}(5)$ & $157.7(3)$ & $\mathrm{C}(1)-\mathrm{C}(2)$ & $151.1(6)$ \\
$\mathrm{P}-\mathrm{C}(2)$ & $180.1(5)$ & $\mathrm{O}(5)-\mathrm{H}(3)$ & $79(6)$
\end{tabular}

\begin{tabular}{llll}
\hline Bond angles $\left(^{\circ}\right)$ & & & \\
\hline $\mathrm{O}(4)-\mathrm{P}-\mathrm{O}(3)$ & $115.3(2)$ & $\mathrm{O}(1)-\mathrm{C}(1)-\mathrm{C}(2)$ & $119.7(4)$ \\
$\mathrm{O}(3)-\mathrm{P}-\mathrm{O}(5)$ & $110.0(2)$ & $\mathrm{O}(2)-\mathrm{C}(1)-\mathrm{C}(2)$ & $119.2(4)$ \\
$\mathrm{O}(4)-\mathrm{P}-\mathrm{O}(5)$ & $106.6(2)$ & $\mathrm{C}(1)-\mathrm{C}(2)-\mathrm{P}$ & $116.0(3)$
\end{tabular}

$\begin{array}{llll}\mathrm{O}(3)-\mathrm{P}-\mathrm{C}(2) & \mathrm{O}(2) & \mathrm{O}(5)-\mathrm{P}-\mathrm{C}(2) & 106.3(2)\end{array}$

$\mathrm{O}(4)-\mathrm{P}-\mathrm{C}(2)$

$110.3(2)$

$\mathrm{O}(2)-\mathrm{C}(1)-\mathrm{O}(1)$

121.1(4)

Neighbouring ribbons of copper polyhedra are linked by the $\left[\mathrm{O}_{3} \mathrm{PC}\right]$ tetrahedra through $\mathrm{O}(3)$ and $\mathrm{O}(4)$ to form infinite layers parallel to ( 01) (Figure 4). The layers are stacked in a ...ABAB... sequence along the [101] direction (Figure 5).

$\mathrm{Cu}\left[\mu_{2}-\mathrm{OOC}\left(\mathrm{CH}_{2}\right) \mathrm{PO}_{3} \mathrm{H}\right] \cdot 2 \mathrm{H}_{2} \mathrm{O}$ (1) can be regarded as the protonated form of a cation exchanger with a layer-like structure. The theoretical exchange capacity is $4.2 \mathrm{mval} \mathrm{g}^{-1}$. The surface charge density of the deprotonated layers was calculated as $0.047 \cdot 10^{-4} \mathrm{e} \cdot \mathrm{pm}^{-2}\left(21.3 \cdot 10^{4} \mathrm{pm}^{2}\right.$ per unit charge), which is close to the values found in layered silicates like Muscovite, Zinnwaldite, and Celadonite. ${ }^{[34]}$

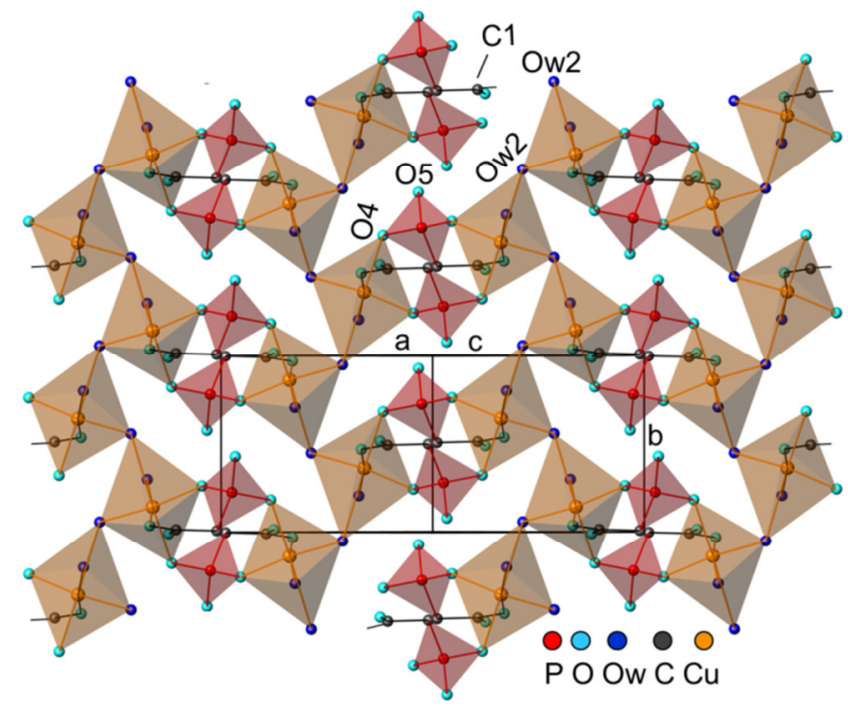

Figure 4. View on a selected layer in the ( $\left.{ }^{-} 01\right)$ plane formed through the connection between the $\mathrm{Cu}^{2+}$ polyhedra ribbons and the $\left[\mathrm{O}_{3} \mathrm{PC}\right]$ tetrahedra in 1 . Hydrogen atoms are omitted for clarity. 


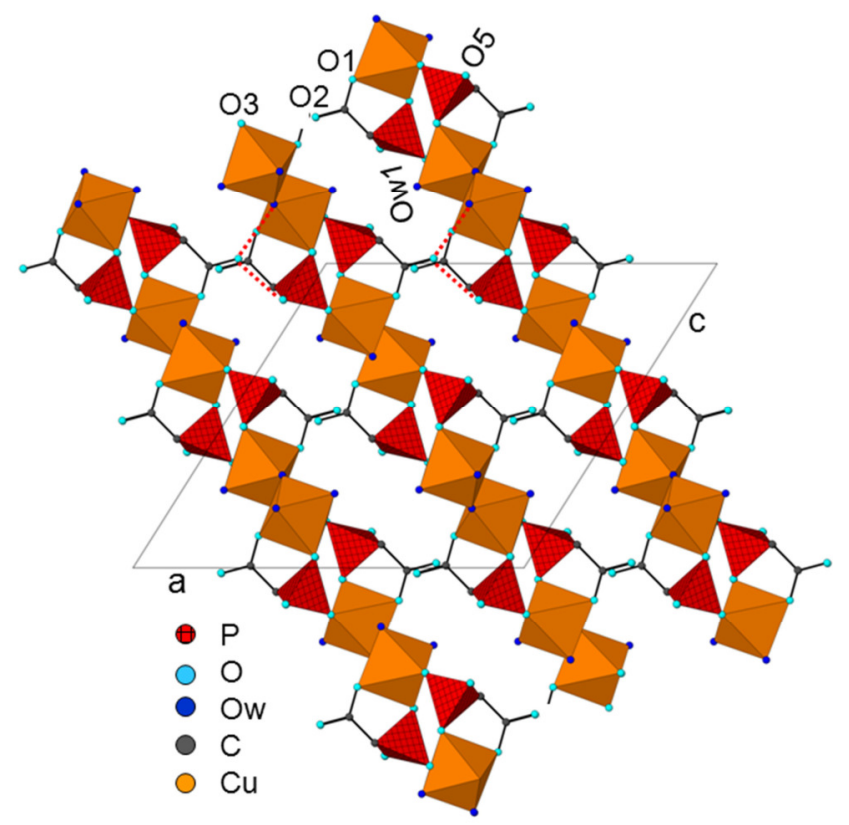

Figure 5. Stacking of the layers along (101) in 1. The red dashed lines show a section of the hydrogen bonds between neighbouring layers. Hydrogen atoms are omitted for clarity.

The layers are linked by hydrogen bonds (Table 3 ). The hydroxo group $\mathrm{O}(5)-\mathrm{H}(2)$ from the hydrogenphosphonoacetate dianion and the water molecule $\mathrm{O}$ (w2) act as proton donators to form hydrogen bonds to the carboxylate oxygen atom $\mathrm{O}(2)$ of the neighbouring layer of rather high and medium strength (Figure 5, Table 3). The water molecules $\mathrm{O}(\mathrm{w} 1)$ and $\mathrm{O}(\mathrm{w} 2)$ are involved in medium strength hydrogen bonds within the same layer to the carboxylate oxygen atom $\mathrm{O}(1)$ and to the phosphonate oxygen atoms $\mathrm{O}(1), \mathrm{O}(4)$, and $\mathrm{O}(5)$. The phosphonate oxygen atom $\mathrm{O}(3)$ is not involved in any hydrogen bond.

Lodhia et al. ${ }^{[24]}$ reported on a triclinic copper hydrogenphosphonoacetate monohydrate in which each hydrogenphosphonoacetate dianion is coordinated to three $\mathrm{Cu}^{2+}$ cations.

\begin{tabular}{|c|c|c|}
\hline & O...O Distance (pm) & $\mathrm{O}-\mathrm{H} \cdots \mathrm{O}$ Angle $\left({ }^{\circ}\right)$ \\
\hline $\mathrm{O}(5)-\mathrm{H}(3) \cdots \mathrm{O}(2)^{[\mathrm{a}]}$ & $259.5(4)$ & $170(7)$ \\
\hline $\mathrm{O}(\mathrm{w} 1)-\mathrm{H}(12) \cdots \mathrm{O}(5)$ & $280.7(5)$ & $171(6)$ \\
\hline $\mathrm{O}(\mathrm{w} 1)-\mathrm{H}(11) \cdots \mathrm{O}(1)$ & $280.9(4)$ & $165(6)$ \\
\hline $\mathrm{O}(\mathrm{w} 2)-\mathrm{H}(21) \cdots \mathrm{O}(2)^{[\mathrm{a}]}$ & $270.9(5)$ & $160(5)$ \\
\hline $\mathrm{O}(\mathrm{w} 2)-\mathrm{H}(22) \cdots \mathrm{O}(4)$ & $271.4(5)$ & $169(5)$ \\
\hline
\end{tabular}

[a] hydrogen bond to neighbouring layers

$\mathrm{O}(\mathrm{w} 1)-\mathrm{H}(11):$ 70(5) pm, O(w1)-H(12): 68(5) pm

$\mathrm{O}(\mathrm{w} 2)-\mathrm{H}(21)$ : 81(5) pm, O(w2)-H(22): 99(5) pm

\section{$\mathrm{Cu}_{1.5}\left[\mu_{3}-\mathrm{OOC}\left(\mathrm{CH}_{2}\right) \mathrm{PO}_{3}\right] \cdot 5 \mathrm{H}_{2} \mathrm{O}(2)$}

There are two crystallographically independent $\mathrm{Cu}^{2+}$ cations. $\mathrm{Cu}(1)$ occupies the general position, whereas $\mathrm{Cu}(2)$ lies on a crystallographic inversion centre (Wyckoff position 1a) of space group . The $\mathrm{Cu}(1)$ cations are five coordinated in a distorted square pyramidal fashion (Figure 6 ). The equatorial positions are formed by three phosphonoacetate oxygen atoms $[O(1)$, $\mathrm{O}(3), \mathrm{O}(4)$ ] stemming from two, but crystallographically equivalent, phosphonoacetate trianions and one water molecule $\mathrm{O}(\mathrm{w} 1)$. The phosphonoacetate trianion coordinates with both the carboxylate group and the phosphonate group (Figure 7). The $\mathrm{Cu}(1)-\mathrm{O}$ distances in the equatorial plane range from 192.9(2) to 198.1(2) pm (Table 4). The best least-square-plane through $\mathrm{Cu}(1), \mathrm{O}(1), \mathrm{O}(3), \mathrm{O}(4)$, and $\mathrm{O}(\mathrm{w} 1)$ shows only minor deviations from planarity (maximum deviation $3.1 \mathrm{pm}$ ). The oxygen atom $\mathrm{O}(4)^{\# 1}$, from a third phosphonoacetate trianion, coordinates $\mathrm{Cu}(1)$ in the axial positions with a longer distance of 229.9(2) pm. Thus the $\mathrm{Cu}(1)$ coordination polyhedron can be approximately described with a $\mathrm{C}_{2 \mathrm{v}}$ point group symmetry. Two $\mathrm{Cu}(1)$ coordination polyhedra, correlated by an inversion centre, are linked by a common edge [2x $\mathrm{O}(4)]$ which leads to dimeric $\left[\mathrm{Cu}_{2}(\mathrm{O})_{6}\left(\mathrm{H}_{2} \mathrm{O}\right)_{2}\right]$ units. The shortest $\mathrm{Cu}(1) \cdots \mathrm{Cu}(1)$ contact is $319.9(1) \mathrm{pm} . \mathrm{Cu}(2)$ is surrounded by six water molecules [2x $\mathrm{O}(\mathrm{w} 2), 2 \mathrm{x} O(\mathrm{w} 3), 2 \mathrm{x} O(\mathrm{w} 4)]$ to from an elongated octahedron $(\mathrm{CN}: 4+2)$ (Figure 6). The $\mathrm{Cu}(2)-\mathrm{O}$ distances in the equatorial plane do not differ significantly from each other (196.8(3)-197.0(2) pm). The axial positions [O(w3)] feature a larger bond length of 237.2(2) pm. Thus the coordination polyhedron of $\mathrm{Cu}(2)$ has $\mathrm{D}_{4 \mathrm{~h}}$ symmetry in good approximation. According to Brese and O'Keeffe [33] the bond order for $\mathrm{Cu}(1)$ and $\mathrm{Cu}(2)$ is calculated to 1.97 and 2.25 , respectively.

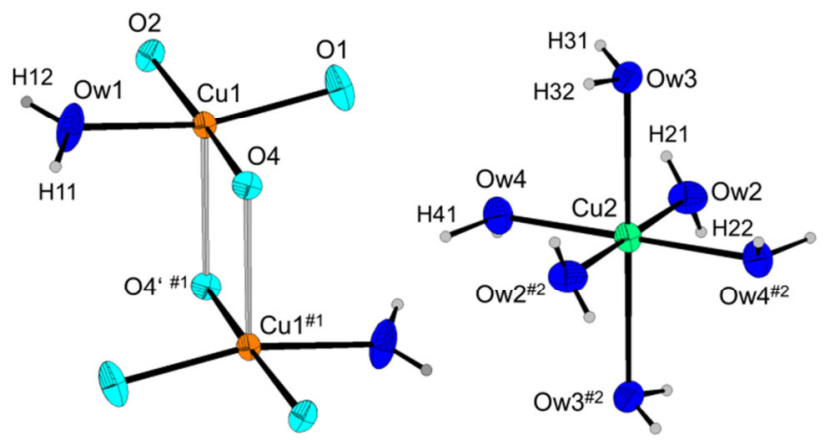

Figure 6. The coordination spheres of $\mathrm{Cu}(1)$ and $\mathrm{Cu}(2)$ in $\mathrm{Cu}_{1.5}\left[\mu_{3}-\right.$ $\left.\mathrm{OOC}\left(\mathrm{CH}_{2}\right) \mathrm{PO}_{3}\right] \cdot 5 \mathrm{H}_{2} \mathrm{O}(2)$. Ellipsoids are given at $50 \%$ probability, arbitrary radii for hydrogen atoms. The index (") indicates the longest $\mathrm{Cu}-\mathrm{O}(4)$ bond which is drawn with a light-grey bond. Symmetry codes as in Table 4. 
Table 4. The coordination of $\mathrm{Cu}^{2+}$ in $\mathrm{Cu}_{1.5}\left[\mu_{3}-\mathrm{OOC}\left(\mathrm{CH}_{2}\right) \mathrm{PO}_{3}\right] \cdot 5 \mathrm{H}_{2} \mathrm{O}(2)$

\begin{tabular}{|c|c|c|c|}
\hline \multicolumn{4}{|l|}{ Distances (pm) } \\
\hline $\mathrm{Cu}(1)-\mathrm{O}(1)$ & 192.9(2) & $\mathrm{Cu}(2)-\mathrm{O}(\mathrm{w} 2)$ & 196.8(3) \\
\hline $\mathrm{Cu}(1)-\mathrm{O}(3)$ & 196.0(2) & $\mathrm{Cu}(2)-\mathrm{O}(\mathrm{w} 2)^{\# 2}$ & 196.8(3) \\
\hline $\mathrm{Cu}(1)-\mathrm{O}(\mathrm{w} 1)$ & 194.6(2) & $\mathrm{Cu}(2)-\mathrm{O}(\mathrm{w} 3)$ & 237.2(2) \\
\hline $\mathrm{Cu}(1)-\mathrm{O}(4)$ & 198.1(2) & $\mathrm{Cu}(2)-\mathrm{O}(\mathrm{w} 3)^{\# 2}$ & $237.2(2)$ \\
\hline \multirow[t]{2}{*}{$\mathrm{Cu}(1)-\mathrm{O}\left(4^{\prime}\right)^{\# 1}$} & 229.9(3) & $\mathrm{Cu}(2)-\mathrm{O}(\mathrm{w} 4)$ & $197.0(2)$ \\
\hline & & $\mathrm{Cu}(2)-\mathrm{O}(\mathrm{w} 4)^{\# 2}$ & $197.0(2)$ \\
\hline $\mathrm{Cu}(1) \cdots \mathrm{Cu}(1)^{\# 1}$ & $319.9(1)$ & & \\
\hline \multicolumn{4}{|l|}{ Bond angles $\left({ }^{\circ}\right)$} \\
\hline $\mathrm{O}(1)-\mathrm{Cu}(1)-\mathrm{O}(\mathrm{w} 1)$ & $163.07(11)$ & $\mathrm{O}(\mathrm{w} 2)-\mathrm{Cu}(2)-\mathrm{O}(\mathrm{w} 2)^{\# 2}$ & $\$ 2 \quad 180$ \\
\hline $\mathrm{O}(\mathrm{w} 1)-\mathrm{Cu}(1)-\mathrm{O}(3)$ & $87.65(10)$ & $\mathrm{O}(\mathrm{w} 2)-\mathrm{Cu}(2)-\mathrm{O}(\mathrm{w} 3)$ & $93.39(9)$ \\
\hline $\mathrm{O}(\mathrm{w} 1)-\mathrm{Cu}(1)-\mathrm{O}(4)$ & $86.60(9)$ & $\mathrm{O}(\mathrm{w} 4)-\mathrm{Cu}(2)-\mathrm{O}(\mathrm{w} 3)$ & $89.84(9)$ \\
\hline $\mathrm{O}(1)-\mathrm{Cu}(1)-\mathrm{O}(4)^{\# 1}$ & $99.79(8)$ & $\mathrm{O}(\mathrm{w} 2)-\mathrm{Cu}(2)-\mathrm{O}(\mathrm{w} 4)$ & $90.46(10)$ \\
\hline $\mathrm{O}(3)-\mathrm{Cu}(1)-\mathrm{O}\left(4^{\prime}\right)^{\# 1}$ & $101.23(8)$ & $\mathrm{O}(\mathrm{w} 4)-\mathrm{Cu}(2)-\mathrm{O}(\mathrm{w} 4)^{\# 2}$ & $\$ 2 \quad 180$ \\
\hline $\mathrm{O}(1)-\mathrm{Cu}(1)-\mathrm{O}(3)$ & $93.68(9)$ & $\mathrm{O}(\mathrm{w} 3)-\mathrm{Cu}(2)-\mathrm{O}(\mathrm{w} 3)^{\# 2}$ & $\$ 2 \quad 180$ \\
\hline $\mathrm{O}(1)-\mathrm{Cu}(1)-\mathrm{O}(4)$ & $90.63(9)$ & $\mathrm{Cu}(1)-\mathrm{O}(4)-\mathrm{Cu}(1)^{\# 1}$ & $96.47(8)$ \\
\hline $\mathrm{O}(3)-\mathrm{Cu}(1)-\mathrm{O}(4)$ & $172.92(8)$ & & \\
\hline $\mathrm{O}(\mathrm{w} 1)-\mathrm{Cu}(1)-\mathrm{O}\left(4^{\prime}\right)^{\# 1}$ & $96.49(10)$ & & \\
\hline $\mathrm{O}(4)-\mathrm{Cu}(1)-\mathrm{O}\left(4^{\prime}\right)^{\# 1}$ & $83.53(8)$ & & \\
\hline
\end{tabular}

Symmetry codes: The index (') indicates the longest $\mathrm{Cu}-\mathrm{O}$ bond. \#1: $-\mathrm{x},-\mathrm{y}-1$, $\mathrm{z}-1$; \#2: $-\mathrm{x},-\mathrm{y},-\mathrm{z}$

The phosphonoacetate anion is completely deprotonated. The phosphorous atom of this trianion in $\mathrm{Cu}_{1.5}\left[\mu_{3}-\right.$ $\left.\mathrm{OOC}\left(\mathrm{CH}_{2}\right) \mathrm{PO}_{3}\right] \cdot 5 \mathrm{H}_{2} \mathrm{O}(2)$ is bound to three oxygen atoms and one carbon atom from the ethylene group in a distorted tetrahedral fashion. The $\mathrm{P}-\mathrm{O}$ bonds range from 152.1(2) to $154.0(2) \mathrm{pm}$, whereas the $\mathrm{P}-\mathrm{C}$ bond is $181.4(3) \mathrm{pm}$. The angles within the $\left[\mathrm{O}_{3} \mathrm{PC}\right]$ tetrahedron differ slightly from the ideal value (Table 5). The $\mathrm{C}-\mathrm{O}$ bond lengths in the carboxylate group do not differ significantly from each other, although only $O(1)$ is coordinated to $\mathrm{Cu}(1)$. The torsion angle between the carboxylate group and a plane through $\mathrm{O}(4)-\mathrm{P}-\mathrm{C}(2)-\mathrm{C}(1)$ is $68.0(2)^{\circ}$. The phosphonate group is coordinated to three $\mathrm{Cu}(1)$ cations and the carboxylate group to one $\mathrm{Cu}(1)$ in a monodentate manner. Thus each phosphonoacetate trianion connects three copper ions and adopts a $\mu_{3}$ coordination mode in which the $\left[\mathrm{PO}_{3}\right]$ group shows a $\mu_{3}-\eta_{1}: \eta_{1}: \eta$ and the carboxylate group a $\mu_{1}-\eta_{1}$ connection mode (Figure 7). Both the carboxylate oxygen atom $\mathrm{O}(2)$ and the phosphonate atom $\mathrm{O}(5)$ are not coordinated to $\mathrm{Cu}^{2+}$. The coordination of $\mathrm{O}(3)$ and $\mathrm{O}(1)$ to $\mathrm{Cu}(1)$ connects the phosphonate group with the carboxylate group and leads to the formation of six-membered ring $[\mathrm{O}(1)-\mathrm{C}(1)-\mathrm{C}(2)-\mathrm{P}-\mathrm{O}(3)-\mathrm{Cu}(1)]$ similar to the one of compound 1 .

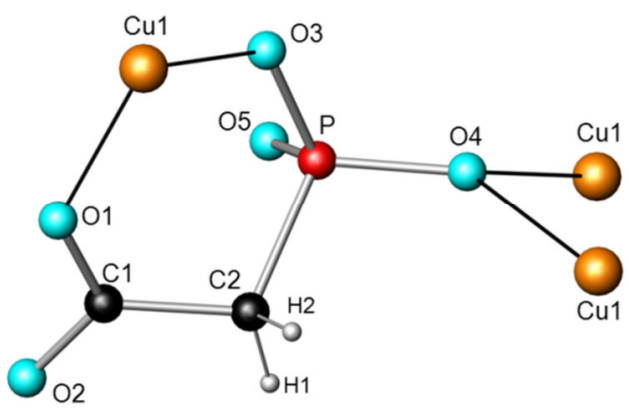

Figure 7. The connection between the phosphonoacetate trianion and the $\mathrm{Cu}(1)$ cations in 2.

Table 5. Bond length and angles of the phosphonoacetate trianion in 2

\begin{tabular}{llcc}
\hline Distances (pm) & & & \\
\hline $\mathrm{P}-\mathrm{O}(3)^{\# 3}$ & $154.0(2)$ & $\mathrm{O}(1)-\mathrm{C}(1)$ & $127.0(4)$ \\
$\mathrm{P}-\mathrm{O}(4)$ & $152.9(2)$ & $\mathrm{O}(2)-\mathrm{C}(1)$ & $126.0(3)$ \\
$\mathrm{P}-\mathrm{O}(5)$ & $152.1(2)$ & $\mathrm{C}(1)-\mathrm{C}(2)$ & $150.2(4)$ \\
$\mathrm{P}-\mathrm{C}(2)^{\# 3}$ & $181.4(3)$ & & \\
\hline $\mathrm{Bond}$ angles $\left(^{\circ}\right)$ & & & $106.05(12)$ \\
\hline $\mathrm{O}(5)-\mathrm{P}-\mathrm{O}(4)$ & $112.40(12)$ & $\mathrm{O}(3)^{\# 3}-\mathrm{P}-\mathrm{C}(2)^{\# 3}$ & $120.1(3)$ \\
$\mathrm{O}(5)-\mathrm{P}-\mathrm{O}(3)^{\# 3}$ & $111.46(11)$ & $\mathrm{O}(2)-\mathrm{C}(1)-\mathrm{O}(1)$ & $119.0(2)$ \\
$\mathrm{O}(4)-\mathrm{P}-\mathrm{O}(3)^{\# 3}$ & $110.68(11)$ & $\mathrm{O}(1)-\mathrm{C}(1)-\mathrm{C}(2)$ & $120.9(3)$ \\
$\mathrm{O}(5)-\mathrm{P}-\mathrm{C}(2)^{\# 3}$ & $109.12(12)$ & $\mathrm{O}(2)-\mathrm{C}(1)-\mathrm{C}(2)$ & $111.8(2)$ \\
$\mathrm{O}(4)-\mathrm{P}-\mathrm{C}(2)^{\# 3}$ & $106.82(12)$ & $\mathrm{C}(1)-\mathrm{C}(2)-\mathrm{P}^{\# 4}$ & \\
\hline
\end{tabular}

Symmetry codes: \#3: $x+1, y, z ; \# 4: x-1, y, z$

In 2, the coordination of the phosphonoacetate trianions to the $\mathrm{Cu}(1)$ cations leads to infinite chain-like polyanions with $\left\{\mathrm{Cu}\left(\mathrm{H}_{2} \mathrm{O}\right)\left[\mathrm{OOC}\left(\mathrm{CH}_{2}\right) \mathrm{PO}_{3}\right]\right\}_{n}{ }^{n-}$ composition (Figure 8). The centrosymmetric polyanionic double chains extend along [100] and are stacked in ...AAA... sequence in both the [010] and [001] direction. The negative excess charge of the chains is compensated for by hydrated $\mathrm{Cu}(2)$ cations $\left(\left[\mathrm{Cu}\left(\mathrm{H}_{2} \mathrm{O}\right)_{6}\right]^{2+}\right)$ which are intercalated between neighbouring chains (Figure 9). Therefore, $\mathrm{Cu}_{1.5}\left[\mu_{3}-\mathrm{OOC}\left(\mathrm{CH}_{2}\right) \mathrm{PO}_{3}\right] \cdot 5 \mathrm{H}_{2} \mathrm{O}$ can be regarded as a chain-like cation exchanger loaded with $\left[\mathrm{Cu}\left(\mathrm{H}_{2} \mathrm{O}\right)_{6}\right]^{2+}$. The theoretical exchange capacity of the $\left\{\mathrm{Cu}\left(\mathrm{H}_{2} \mathrm{O}\right)\left[\mu_{3}-\right.\right.$ $\left.\left.\mathrm{OOC}\left(\mathrm{CH}_{2}\right) \mathrm{PO}_{3}\right]\right\}_{n}{ }^{n-}$ polyanionic chains is calculated to $4.6 \mathrm{mval}$ $\mathrm{g}^{-1}$ with a linear charge density of $0.164 \cdot 10^{-2} \mathrm{e} \cdot \mathrm{pm}^{-1}(608 \mathrm{pm}$ per unit charge). The water molecule $\mathrm{O}(\mathrm{w} 1)$, bound to $\mathrm{Cu}(1)$, forms a medium strength hydrogen bond to $\mathrm{O}(2)$ from a neighbouring 
chain (Table 6, Figure 10). Furthermore, the polyanionic chains are linked by hydrogen bonds via the hydrated $\mathrm{Cu}(2)$ cation and the non-coordinating water molecule $\mathrm{O}(\mathrm{w} 5)$. The coordinating water molecules $\mathrm{O}(\mathrm{w} 2), \mathrm{O}(\mathrm{w} 3)$, and $\mathrm{O}(\mathrm{w} 4)$ of the $\mathrm{Cu}(2)$ cation form strong and medium strength hydrogen bonds to the carboxylate oxygen atom $\mathrm{O}(2)$ and to the phosphonate oxygen atoms $\mathrm{O}(3)$ and $\mathrm{O}(5)$ from the phosphonoacetate anion as well as to the coordinated water molecule $\mathrm{O}(\mathrm{w} 1)$. A rather weak hydrogen bond is formed between the water molecule $\mathrm{O}(\mathrm{w} 3)$ and $O(1)$. The non-coordinating water molecule $O(w 5)$ acts as proton donator to $\mathrm{O}(5) . \mathrm{O}(\mathrm{w} 1), \mathrm{O}(\mathrm{w} 2)$, and $\mathrm{O}(\mathrm{w} 4)$ act as proton donators in medium strength hydrogen bonds to $\mathrm{O}(\mathrm{w} 3)$ and $\mathrm{O}(\mathrm{w} 5)$. The phosphonate oxygen atom $\mathrm{O}(4)$ is not involved in any hydrogen bonds.

Similar structures with polyanionic chains and cation exchanger features were found in e.g. dicobalt-1,2,4,5benzenetetracarboxylate octadecahydrate and hexaaquacadmium(II)-catena-[bis(4-amino-1,2,4-triazole)tetraaquabis -(benzene-1,3,5-tricarboxylato)-dicadmate(II)] dihydrate. ${ }^{[35,36]}$

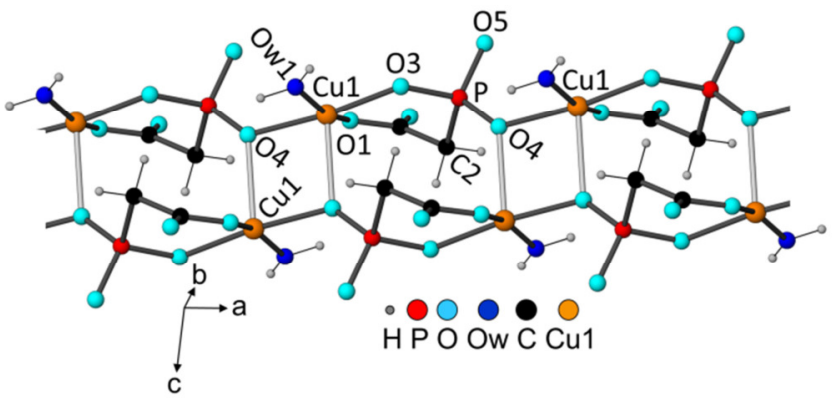

Figure 8. Coordination between $\mathrm{Cu}(1)$ cations and $\left.\left[\mathrm{OOC}\left(\mathrm{CH}_{2}\right) \mathrm{PO}_{3}\right)\right]^{3-}$ anions to infinite polyanionic double chains along [100] in 2. The longest $\mathrm{Cu}-\mathrm{O}(4)$ bond is drawn with a light-grey bond.

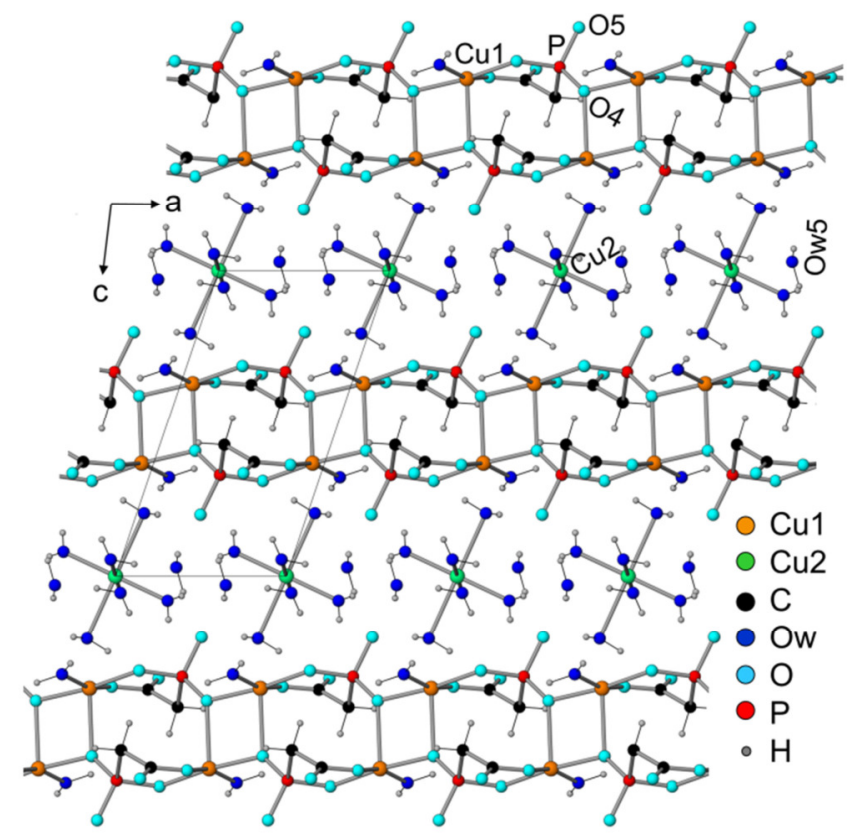

Figure 9. Crystal structure of $\mathrm{Cu}_{1.5}\left[\mu_{3}-\mathrm{OOC}\left(\mathrm{CH}_{2}\right) \mathrm{PO}_{3}\right] \cdot 5 \mathrm{H}_{2} \mathrm{O}$ (2) viewed from [010].

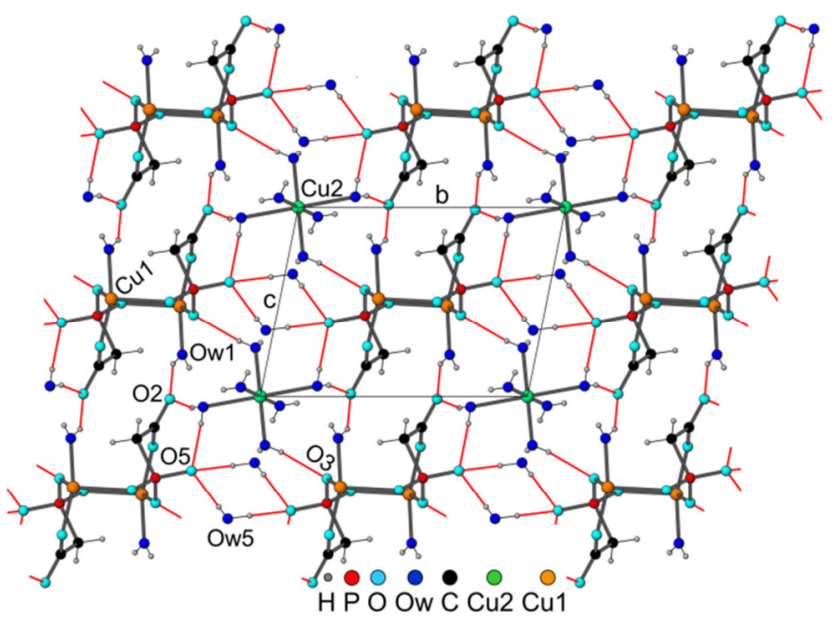

Figure 10. Structure of 2 with hydrogen bonds (thin red lines) viewed from [100]. The rather weak hydrogen bond between $O(w 3)$ and $O(1)$ as well as hydrogen bonds between water molecules are omitted for clarity. 


\begin{tabular}{lcc}
\hline \multicolumn{2}{l}{ Table 6. Hydrogen bonds in 2} & \\
\hline & $\mathrm{O} \cdots \mathrm{O}$ Distance (pm) & $\mathrm{O}-\mathrm{H} \cdots \mathrm{O}$ Angle $\left(^{\circ}\right)$ \\
\hline $\mathrm{O}(\mathrm{w} 1)-\mathrm{H}(11) \cdots \mathrm{O}(2)^{[a]}$ & $268.9(4)$ & $151(4)$ \\
$\mathrm{O}(\mathrm{w} 1)-\mathrm{H}(12) \cdots \mathrm{O}(\mathrm{w} 3)$ & $268.3(4)$ & $172(5)$ \\
$\mathrm{O}(\mathrm{w} 2)-\mathrm{H}(22) \cdots \mathrm{O}(2)$ & $280.5(3)$ & $168(5)$ \\
$\mathrm{O}(\mathrm{w} 2)-\mathrm{H}(21) \cdots \mathrm{O}(\mathrm{w} 5)$ & $271.3(3)$ & $176(5)$ \\
$\mathrm{O}(\mathrm{w} 3)-\mathrm{H}(31) \cdots \mathrm{O}(5)$ & $275.7(3)$ & $175(5)$ \\
$\mathrm{O}(\mathrm{w} 3)-\mathrm{H}(32) \cdots \mathrm{O}(2)$ & $286.2(4)$ & $167(5)$ \\
$\mathrm{O}(\mathrm{w} 3)-\mathrm{H}(32) \cdots \mathrm{O}(1)$ & $294.5(4)$ & $130(4)$ \\
$\mathrm{O}(\mathrm{w} 4)-\mathrm{H}(42) \cdots \mathrm{O}(3)$ & $276.9(3)$ & $160(4)$ \\
$\mathrm{O}(\mathrm{w} 4)-\mathrm{H}(41) \cdots \mathrm{O}(\mathrm{w} 5)$ & $272.1(4)$ & $174(5)$ \\
$\mathrm{O}(\mathrm{w} 5)-\mathrm{H}(51) \cdots \mathrm{O}(5)$ & $275.0(3)$ & $175(4)$ \\
$\mathrm{O}(\mathrm{w} 5)-\mathrm{H}(52) \cdots \mathrm{O}(5)$ & $276.7(4)$ & $164(5)$ \\
\hline
\end{tabular}

[a] hydrogen bond to neighbouring chains $\mathrm{O}(\mathrm{w} 1)-\mathrm{H}(11)$ : 90(5) pm, O(w1)-H(12): 73(5) pm $\mathrm{O}(\mathrm{w} 2)-\mathrm{H}(21): 69(4) \mathrm{pm}, \mathrm{O}(\mathrm{w} 2)-\mathrm{H}(22): 68(5) \mathrm{pm}$ $\mathrm{O}(\mathrm{w} 3)-\mathrm{H}(31):$ 70(4) pm, O(w3)-H(32): 90(5) pm $\mathrm{O}(\mathrm{w} 4)-\mathrm{H}(41):$ 96(6) pm, O(w4)-H(42): 73(4) pm $\mathrm{O}(\mathrm{w} 5)-\mathrm{H}(51)$ : 93(4) pm, O(w5)-H(52): 61(5) pm

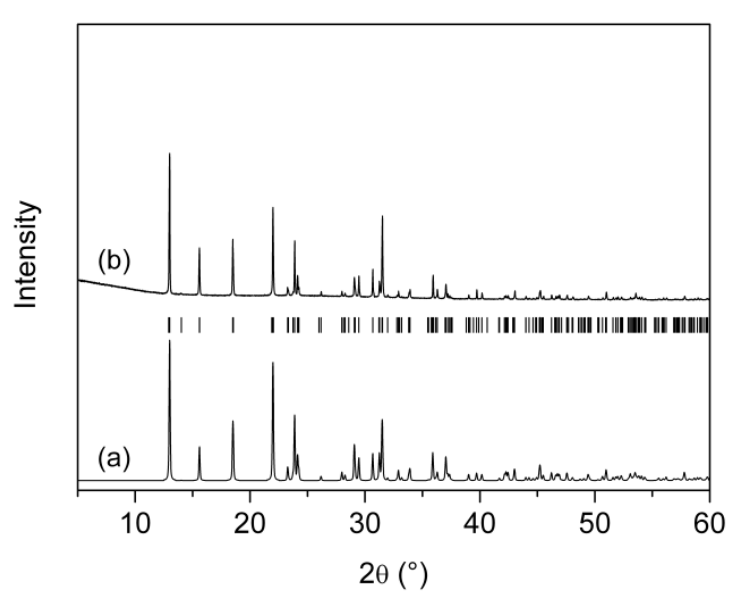

Figure 11. X-ray powder diffraction patterns of $\mathrm{Cu}\left[\mathrm{\mu}_{2}-\mathrm{OOC}\left(\mathrm{CH}_{2}\right) \mathrm{PO}_{3} \mathrm{H}\right] \cdot 2 \mathrm{H}_{2} \mathrm{O}$ (1). (a) calculated pattern, (b) experimental pattern.

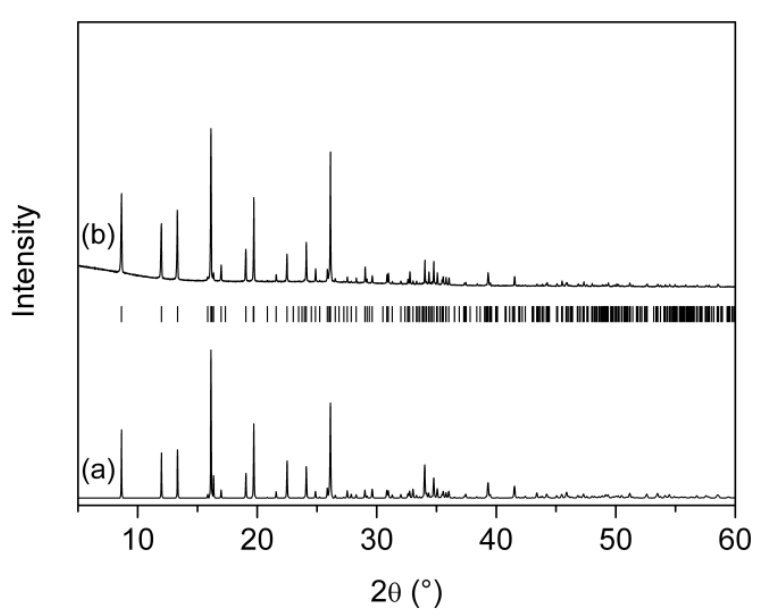

Figure 12. X-ray powder diffraction patterns of $\mathrm{Cu}_{1.5}\left[\mu_{3}-\mathrm{OOC}\left(\mathrm{CH}_{2}\right) \mathrm{PO}_{3}\right] \cdot 5 \mathrm{H}_{2} \mathrm{O}$ (2). (a) calculated pattern, (b) experimental pattern.

Figure 11 and 12 show the XRD patterns of powdered $\mathrm{Cu}\left[\mu_{2}\right.$ $\left.\mathrm{OOC}\left(\mathrm{CH}_{2}\right) \mathrm{PO}_{3} \mathrm{H}\right] \cdot 2 \mathrm{H}_{2} \mathrm{O}(1)$ and $\mathrm{Cu}_{1.5}\left[\mu_{3}-\mathrm{OOC}\left(\mathrm{CH}_{2}\right) \mathrm{PO}_{3}\right] \cdot 5 \mathrm{H}_{2} \mathrm{O}(2)$ crystals together with the calculated patterns obtained from the single crystal data. The experimental patterns match with the calculated patterns. No reflections from secondary phases are visible indicating the syntheses routes lead to single phase products.

TGA/DTA studies were carried out in air from room temperature to $1000{ }^{\circ} \mathrm{C}$ at a heating rate of $10 \mathrm{~K} \mathrm{~min}^{-1}$. $\mathrm{Cu}\left[\mu_{2}-\right.$ $\left.\mathrm{OOC}\left(\mathrm{CH}_{2}\right) \mathrm{PO}_{3} \mathrm{H}\right] \cdot 2 \mathrm{H}_{2} \mathrm{O}$ (1) is stable up to $165^{\circ} \mathrm{C}$ (Figure 13). A following endothermic process with an onset temperature of $167^{\circ} \mathrm{C}$ causes a weight loss of $14.3 \%$ up to $233^{\circ} \mathrm{C}$. This weight loss corresponds to the loss of two water molecules per formula unit (calcd. $15.2 \%$ ). Strong exothermic reactions with onset temperatures of about 250,340 , and $490{ }^{\circ} \mathrm{C}$ lead to the complete decomposition up to $640{ }^{\circ} \mathrm{C}$. X-ray powder diffraction of the colourless residue showed reflections of $\mathrm{Cu}_{2} \mathrm{P}_{2} \mathrm{O}_{7}$ and small traces of $\mathrm{Cu}_{3}\left(\mathrm{PO}_{4}\right)_{2}$. The total weight loss of $37.6 \%$ is close to the calculated one of $36.6 \%$ for pure $\mathrm{Cu}_{2} \mathrm{P}_{2} \mathrm{O}_{7}$ as the final product. As seen in Figure 14 the decomposition of $\mathrm{Cu}_{1.5}\left[\mu_{3}-\mathrm{OOC}\left(\mathrm{CH}_{2}\right) \mathrm{PO}_{3}\right] \cdot 5 \mathrm{H}_{2} \mathrm{O}$ (2) starts at $63{ }^{\circ} \mathrm{C}$. The endothermic reaction with an onset temperature of $65^{\circ} \mathrm{C}$ leads up to $138{ }^{\circ} \mathrm{C}$ to a weight loss of $21.4 \%$. A following smaller second weight loss caused by a weak endothermic process (onset at $180{ }^{\circ} \mathrm{C}$ ) results up to $300{ }^{\circ} \mathrm{C}$ in a total weight loss of $27.2 \%$. This weight loss corresponds well to the loss of five water molecules per formula unit (calcd. $27.9 \%$ ). Further heating leads to several very strong and fast decomposition steps accompanied by exothermic processes with onset temperatures of 304,328 , and $576{ }^{\circ} \mathrm{C}$. The decomposition is finished at $590{ }^{\circ} \mathrm{C}$. The blue residue was identified as triclinic $\mathrm{Cu}_{3}\left(\mathrm{PO}_{4}\right)_{2}$ by $\mathrm{X}$-ray powder diffraction. The total weight loss of $41.3 \%$ matches very well with the calculated one of $41.0 \%$. 


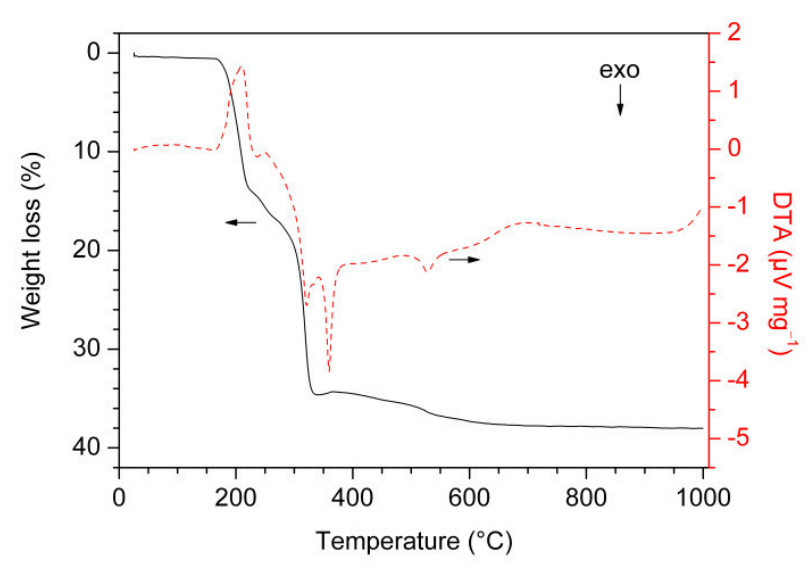

Figure 13. Thermal analysis of $\mathrm{Cu}\left[\mu_{2}-\mathrm{OOC}\left(\mathrm{CH}_{2}\right) \mathrm{PO}_{3} \mathrm{H}\right] \cdot 2 \mathrm{H}_{2} \mathrm{O}(1)$.

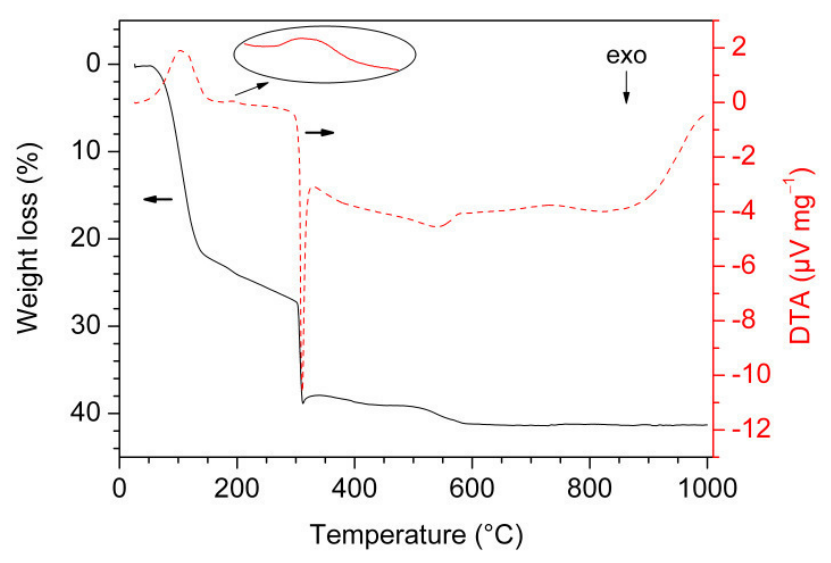

Figure 14. Thermal analysis of $\mathrm{Cu}_{1.5}\left[\mu_{3}-\mathrm{OOC}\left(\mathrm{CH}_{2}\right) \mathrm{PO}_{3}\right] \cdot 5 \mathrm{H}_{2} \mathrm{O}(2)$.

Figure 15 shows the IR spectra (ATR technique) of $\mathrm{Cu}\left[\mu_{2}-\right.$ $\left.\mathrm{OOC}\left(\mathrm{CH}_{2}\right) \mathrm{PO}_{3} \mathrm{H}\right] \cdot 2 \mathrm{H}_{2} \mathrm{O}(1)$ and $\mathrm{Cu}_{1.5}\left[\mu_{3}-\mathrm{OOC}\left(\mathrm{CH}_{2}\right) \mathrm{PO}_{3}\right] \cdot 5 \mathrm{H}_{2} \mathrm{O}(2)$. The $\mathrm{O}-\mathrm{H}$ stretching vibrations appear in 1 at 3329, 3327, and $3119 \mathrm{~cm}^{-1}$, whereas 2 has a broad band between 3500 and $3000 \mathrm{~cm}^{-1}$. The weak band at $2921 \mathrm{~cm}^{-1}$ in 1 and $2937 \mathrm{~cm}^{-1}$ in 2 is due the $\mathrm{CH}_{2}$ stretching mode. A comparison with copper 1,2ethylenediphosphonate ${ }^{[7]}$ shows that the band at $1413 \mathrm{~cm}^{-1}$ (1) and $1426 \mathrm{~cm}^{-1}(2)$ is caused by the $\mathrm{CH}_{2}$ bending mode, whereas the bands at 1543 and $1392 \mathrm{~cm}^{-1}$ (1) and at 1558 and $1393 \mathrm{~cm}^{-1}$ (2) represent the asymmetric $\left(v_{\text {as }}\right)$ and symmetric $\left(v_{\mathrm{s}}\right)$ vibrations of the carboxylate group, respectively. The carboxylate group coordinates $\mathrm{Cu}^{2+}$ in a monodentate manner (Figure 3 and 7) and therefore a difference between $v_{\text {as }}$ and $v_{\mathrm{s}}$ of $\geq 200 \mathrm{~cm}^{-1}$ should be expected. ${ }^{[37]}$ However, the observed difference of $151 \mathrm{~cm}^{-1}$ (1) and $165 \mathrm{~cm}^{-1}$ (2) suggests a bidentate coordination mode. As shown in Table 3 and 6, the uncoordinated carboxylate oxygen atom $\mathrm{O}(2)$ is involved in several hydrogen bonds, leading to a "pseudo-bidentate" vibration behaviour. ${ }^{[37,38]} \mathrm{P}-\mathrm{O}$ stretching modes appear at 1272,1239, 1151, and $1062 \mathrm{~cm}^{-1}$ (1), and at $1205,1126,1070$, and $1034 \mathrm{~cm}^{-1}(2)$, respectively. ${ }^{[39-41]}$

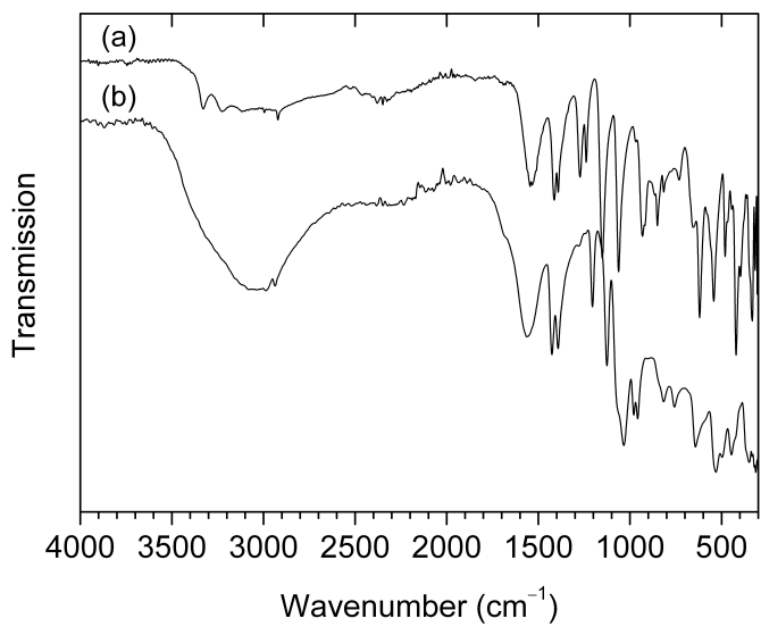

Figure 15. IR spectra of (a) $\mathrm{Cu}\left[\mu_{2}-\mathrm{OOC}\left(\mathrm{CH}_{2}\right) \mathrm{PO}_{3} \mathrm{H}\right] \cdot 2 \mathrm{H}_{2} \mathrm{O}$ (1) and (b) $\mathrm{Cu}_{1.5}\left[\mu_{3^{-}}\right.$ $\left.\mathrm{OOC}\left(\mathrm{CH}_{2}\right) \mathrm{PO}_{3}\right] \cdot 5 \mathrm{H}_{2} \mathrm{O}(2)$.

The magnetic measurements were carried out between 3 and $300 \mathrm{~K} . \mathrm{Cu}\left[\mu_{2}-\mathrm{OOC}\left(\mathrm{CH}_{2}\right) \mathrm{PO}_{3} \mathrm{H}\right] \cdot 2 \mathrm{H}_{2} \mathrm{O}$ (1) shows a paramagnetic behaviour with a Curie constant of $5.73 \cdot 10^{-6} \mathrm{~m}^{3} \mathrm{~K} \mathrm{~mol}^{-1}$. The magnetic moment was calculated as $\mu_{\text {eff }}=1.91 \mu_{\mathrm{B}}$ per formula unit.

The development of the susceptibility of $\mathrm{Cu}_{1.5}\left[\mu_{3^{-}}\right.$ $\left.\mathrm{OOC}\left(\mathrm{CH}_{2}\right) \mathrm{PO}_{3}\right] \cdot 5 \mathrm{H}_{2} \mathrm{O}(2)$ (Figure 16) can be fitted by a CurieWeiss law with a Curie constant of $5.93 \cdot 10^{-6} \mathrm{~m}^{3} \mathrm{~K} \mathrm{~mol}^{-1}$ and a Weiss temperature of $\Theta=-1.39 \mathrm{~K}$. The magnetic moment was calculated as $\mu_{\text {eff }}=1.94 \mu_{\mathrm{B}}$ per $\mathrm{Cu}^{2+}$. The slightly larger value than the theoretical spin only one of $1.73 \mu_{\mathrm{B}}$ per $\mathrm{Cu}^{2+}$ is due to a weak spin-orbital interaction as often found in $\mathrm{Cu}^{2+}$ complexes. ${ }^{[42-44]}$ The temperature dependence of the magnetic moment per $\mathrm{Cu}^{2+}$ in $\mathbf{2}$ is shown in Figure 17. The magnetic moment was calculated considering the Weiss temperature as $\mu_{\text {eff }} / \mu_{B}=797.73\left[\chi_{\text {mol }}(T-\Theta)\right]^{0.5}{ }^{[45]}$ Between 300 and $20 \mathrm{~K}$ the value of the magnetic moment does not change significantly. However, below $20 \mathrm{~K}$ the magnetic moment decreases slightly indicating a possible weak antiferromagnetic interaction between the $\mathrm{Cu}(1)$ cations. An interaction involving $\mathrm{Cu}(2)$ cations can be ruled out. The shortest distance between two $\mathrm{Cu}(1)$ ions is $319.9(1) \mathrm{pm}$, thus a direct exchange coupling can be excluded. A possible superexchange path between two neighbouring $\mathrm{Cu}(1)$ cations involves the phosphonate oxygen atom $\mathrm{O}(4)$ with a small $\mathrm{Cu}(1)-\mathrm{O}(4)-\mathrm{Cu}(1)^{\# 1}$ angle of $96.47(8)^{\circ}$ (Figure 6). According to Crawford et al. ${ }^{[46]}$ and Merz and Haase ${ }^{[47]}$ the $\mathrm{Cu}-\mathrm{O}-\mathrm{Cu}$ angle for a antiferromagnetic interaction in hydroxo- and alkoxide- 
bridged copper centres should be greater than $97.5^{\circ}$ and $95.7^{\circ}$, respectively. $\mathrm{Cu}(1)$ is coordinated in a square pyramidal fashion, thus the magnetic orbital is $d_{x}{ }^{2}-y^{2}$ pointing to the equatorial oxygen atoms $\mathrm{O}(\mathrm{w} 1), \mathrm{O}(1), \mathrm{O}(2)$, and $\mathrm{O}(4) \cdot{ }^{[26]}$ In this case, the magnetic $\mathrm{Cu}-\mathrm{O}-\mathrm{Cu}$ superexchange path should involve only equatorial oxygen atoms between adjacent copper cations. As shown in Figure 6 the two $\mathrm{Cu}(1)$ polyhedra are linked by the oxygen atom $\mathrm{O}(4)$, which occupies the equatorial position (short contact of 198.1(2) pm) of one $\mathrm{Cu}(1)$ polyhedron and simultaneously caps the axial position of the other $\mathrm{Cu}(1)$ polyhedron with a longer distance of 229.9(3) pm. Thus, an antiferromagnetic superexchange via the $\mathrm{Cu}(1)-\mathrm{O}(4)-\mathrm{Cu}(1)^{\# 1}$ path is unlikely, because of the $\mathrm{Cu}-\mathrm{O}-\mathrm{Cu}$ angle close to $90^{\circ}$ and the exchange path involves both axial and equatorial $\mathrm{Cu}-\mathrm{O}$ bonds. Analogous arrangements were also found in e.g. $\mathrm{BaCuP}_{2} \mathrm{O}_{7}$ and $\mathrm{KCuMoO}_{4}(\mathrm{OH}) .^{[48,49]}$

Consequently, a $\mathrm{Cu}-\mathrm{O} \cdots \mathrm{O}-\mathrm{Cu}$ super-superexchange via the $\mathrm{Cu}(1)-\mathrm{O}(4)-\mathrm{P}-\mathrm{O}(3)^{\# 3}-\mathrm{Cu}(1)^{\# 3}$ path, in which the oxygen atoms occupy the equatorial positions, is obviously responsible for the weak antiferromagnetic interaction (Figure 8). The strength of such spin exchange increases with decreasing $\mathrm{O} \cdots \mathrm{O}$ distances and rising $\mathrm{Cu}-\mathrm{O} \cdots \mathrm{O}$ angles. ${ }^{[50]}$ The $\mathrm{O}(4) \cdots \mathrm{O}(3)^{\# 3}$ distance is 252.5(3) pm (smaller than the sum of the van der Waals radii) and the $\mathrm{Cu}(1)-\mathrm{O}(4) \cdots \mathrm{O}(3)^{\# 3}$ and $\mathrm{Cu}(1)^{\# 3}-\mathrm{O}(3)^{\# 3} \cdots \mathrm{O}(4)$ angles are $142.92(14)^{\circ}$ and $136.34(14)^{\circ}$, respectively. The $\mathrm{Cu}(1) \cdots \mathrm{Cu}(1)^{\# 3}$ distance is $608.2(1) \mathrm{pm}$ and the torsion angle of $\mathrm{Cu}(1)-\mathrm{O}(4) \cdots$ $\mathrm{O}(3)^{\# 3}-\mathrm{Cu}(1)^{\# 3}$ accounts to $4.0(2)^{\circ}$. Such super-superexchange paths are also found in e.g. copper phosphates ${ }^{[48,51]}$, sodium copper methylenediphosphonate monohydrate ${ }^{[52]}$, copper hydrogen-3-phosphonopropionate $\left.{ }^{[53}\right]$, and other copper phosphonates $^{[54,55]}$.

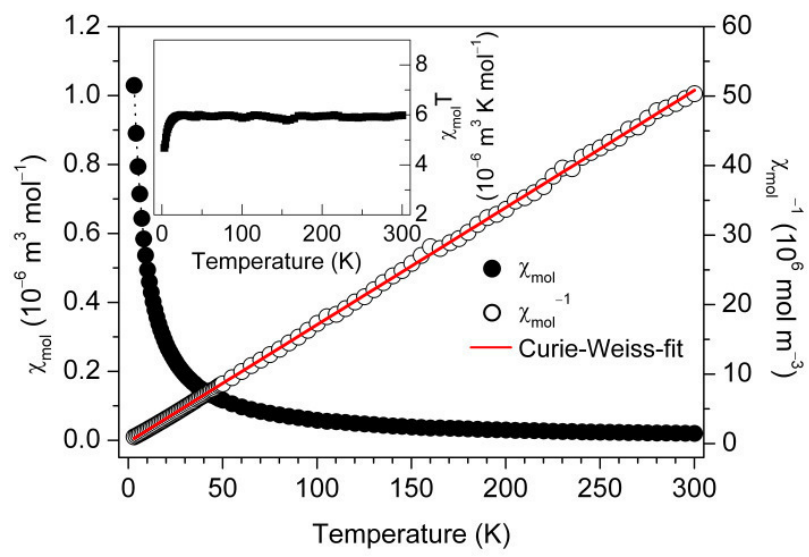

Figure 16. Susceptibility vs. temperature of $\mathrm{Cu}_{1.5}\left[\mu_{3}-\mathrm{OOC}\left(\mathrm{CH}_{2}\right) \mathrm{PO}_{3}\right] \cdot 5 \mathrm{H}_{2} \mathrm{O}(2)$.

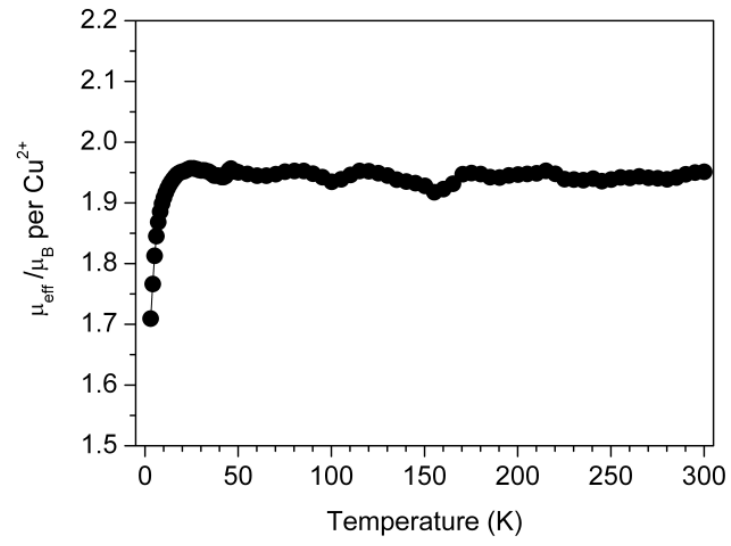

Figure 17. Change of the magnetic moment vs. temperature of $\mathrm{Cu}_{1.5}\left[\mu_{3}\right.$ $\left.\mathrm{OOC}\left(\mathrm{CH}_{2}\right) \mathrm{PO}_{3}\right] \cdot 5 \mathrm{H}_{2} \mathrm{O}$ (2). The magnetic moment was calculated considering the Weiss temperature.

The diffuse reflectance UV/Vis spectrum was recorded for powdered crystals of $\mathrm{Cu}\left[\mu_{2}-\mathrm{OOC}\left(\mathrm{CH}_{2}\right) \mathrm{PO}_{3} \mathrm{H}\right] \cdot 2 \mathrm{H}_{2} \mathrm{O}$ (1) and is shown in Figure 18. A broad asymmetric band appears between 500 and $1400 \mathrm{~nm}$ caused by $\mathrm{d}-\mathrm{d}$ transitions. The measured curve can be well fitted by three bands with maxima at 763,878 , and $1061 \mathrm{~nm}\left(13106,11390\right.$, and $\left.9425 \mathrm{~cm}^{-1}\right)$. The $\mathrm{Cu}^{2+}$ polyhedron can be approximately described by $\mathrm{C}_{4 \mathrm{v}}$ symmetry. Thus, in contrast to an ideal octahedral ligand field $\left(\mathrm{O}_{\mathrm{h}}\right.$ symmetry), the ground state ${ }^{2} E_{g}$ splits into ${ }^{2} B_{1}$ and ${ }^{2} A_{1}$, whereas the ${ }^{2} \mathrm{~T}_{2 g}$ splits into ${ }^{2} \mathrm{~B}_{2}$ and ${ }^{2} \mathrm{E}$ energy levels. According to Tomlinson and Hathaway ${ }^{[56]}$ and Sreeramulu et al. ${ }^{[57]}$ the ground state is ${ }^{2} B_{1}$ and the energy level sequence is ${ }^{2} B_{1}<{ }^{2} A_{1}<{ }^{2} B_{2}<{ }^{2} E$ and therefore three transitions bands are expected. The fitted absorption band at $763 \mathrm{~nm}$ can be assigned as the ${ }^{2} \mathrm{~B}_{1} \rightarrow{ }^{2} \mathrm{E}$ transition, that at $878 \mathrm{~nm}$ as the ${ }^{2} \mathrm{~B}_{1} \rightarrow{ }^{2} \mathrm{~B}_{2}$, and that at $1061 \mathrm{~nm}$ as the ${ }^{2} \mathrm{~B}_{1} \rightarrow{ }^{2} \mathrm{~A}_{1}$ transition. ${ }^{[56]}$ The octahedral and tetragonal crystal field parameters are $\mathrm{Dq}=1139 \mathrm{~cm}^{-1}$, Ds $=1592 \mathrm{~cm}^{-1}$, and $\mathrm{Dt}=611 \mathrm{~cm}^{-1}$. The crystal field parameters were calculated from the observed band positions as $4 \mathrm{Ds}+5 \mathrm{Dt}=8335 \mathrm{~cm}^{-1}$, $10 D q+3 D s-5 D t=13106 \mathrm{~cm}^{-1}$, and $10 D q=11390 \mathrm{~cm}^{-1}$ as described elsewhere. ${ }^{[58]}$ 


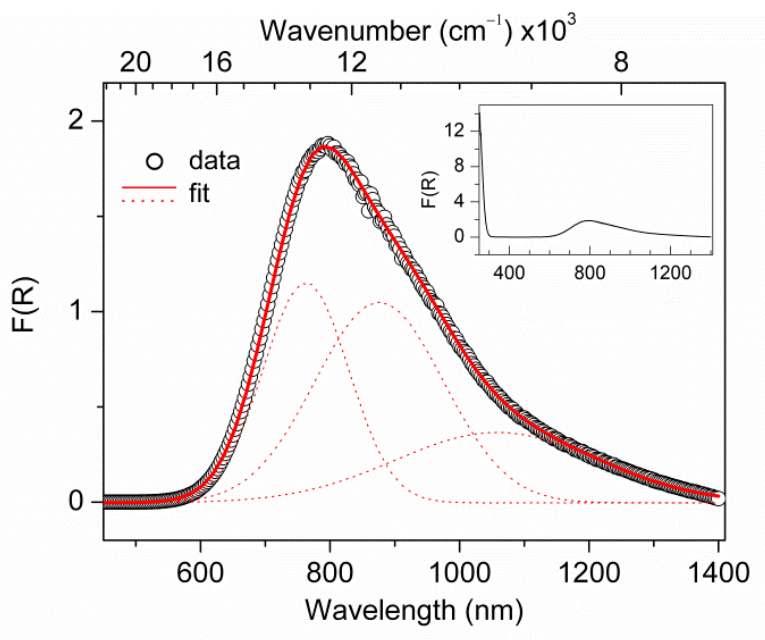

Figure 18. Diffuse reflectance UV/Vis spectrum of powdered $\mathrm{Cu}\left[\mu_{2}\right.$ $\left.\mathrm{OOC}\left(\mathrm{CH}_{2}\right) \mathrm{PO}_{3} \mathrm{H}\right] \cdot 2 \mathrm{H}_{2} \mathrm{O}$ (1). Three Gaussian curves (red dashed lines) were used to fit the spectrum and their sum is presented by the thick red curve. The inset shows the whole spectrum from 250 to $1400 \mathrm{~nm}[\mathrm{~F}(\mathrm{R})=$ Kubelka-MunkFunction]

\section{Conclusions}

The synthesis and crystal structure of $\mathrm{Cu}\left[\mu_{2}-\right.$ $\left.\mathrm{OOC}\left(\mathrm{CH}_{2}\right) \mathrm{PO}_{3} \mathrm{H}\right] \cdot 2 \mathrm{H}_{2} \mathrm{O}(1)$ and $\mathrm{Cu}_{1.5}\left[\mu_{3}-\mathrm{OOC}\left(\mathrm{CH}_{2}\right) \mathrm{PO}_{3}\right] \cdot 5 \mathrm{H}_{2} \mathrm{O}(2)$ is reported herein. In 1 the connection between the $\mathrm{Cu}^{2+}$ cations and the hydrogenphosphonoacetate dianion leads to infinite layers features of cation exchangers. The layers are only connected by hydrogen bonds. Compound 1 is thermally stable up to $165{ }^{\circ} \mathrm{C}$. The UV/Vis spectra show three $\mathrm{d}-\mathrm{d}$ transition bands at 763, 878, and $1061 \mathrm{~nm}$ and the magnetic measurement reveal a paramagnetic Curie-Weiss behaviour. The crystal structure of $\mathbf{2}$ shows infinite centrosymmetric polyanionic chains. The negative excess charge is compensated by hydrated copper cations intercalated between the chains. Thus compound $\mathbf{2}$ can be regarded as a copper loaded cation exchanger. The thermal decomposition starts at $63{ }^{\circ} \mathrm{C}$ and is finished at $590{ }^{\circ} \mathrm{C}$. Magnetic measurements show a paramagnetic behaviour with an obviously weak antiferromagnetic interaction at low temperatures due to a super-superexchange coupling.

\section{Experimental Section}

Single crystals of $\mathrm{Cu}\left[\mu_{2}-\mathrm{OOC}\left(\mathrm{CH}_{2}\right) \mathrm{PO}_{3} \mathrm{H}\right] \cdot 2 \mathrm{H}_{2} \mathrm{O}$ (1) can be synthesized in aqueous solution in two ways. $0.002 \mathrm{~mol}$ phosphonoacetic acid, 0.001 $\mathrm{mol} \mathrm{Cu}\left(\mathrm{NO}_{3}\right)_{2} \cdot 3 \mathrm{H}_{2} \mathrm{O}$ and $0.001 \mathrm{~mol}$ tetraethylammonium chloride were dissolved in $7.5 \mathrm{ml}$ deionized water. $1 \mathrm{M} \mathrm{NaOH}$ solution was added until a $\mathrm{pH}$ value of 3 was reached. The clear solution was kept at room temperature. After four days blue crystals appeared. ${ }^{[59]} \mathrm{A}$ second way to obtain $\mathrm{Cu}\left[\mu_{2}-\mathrm{OOC}\left(\mathrm{CH}_{2}\right) \mathrm{PO}_{3} \mathrm{H}\right] \cdot 2 \mathrm{H}_{2} \mathrm{O}$ is given by the following convenient procedure. $0.001 \mathrm{~mol}$ phosphonoacetic acid, $0.002 \mathrm{~mol} \mathrm{Cu}\left(\mathrm{NO}_{3}\right) \cdot 3 \mathrm{H}_{2} \mathrm{O}$, and $50 \mathrm{mg}$ urea were dissolved in $5 \mathrm{ml}$ water in a round bottom flask and kept at $80^{\circ} \mathrm{C}$ in a drying oven. After two days blue crystals were formed.
Crystals of $\mathrm{Cu}_{1.5}\left[\mu_{3}-\mathrm{OOC}\left(\mathrm{CH}_{2}\right) \mathrm{PO}_{3}\right] \cdot 5 \mathrm{H}_{2} \mathrm{O}$ (2) can be obtained from aqueous solution. $0.002 \mathrm{~mol}$ phosphonoacetic acid and $0.001 \mathrm{~mol}$ $\mathrm{Cu}\left(\mathrm{NO}_{3}\right)_{2} \cdot 3 \mathrm{H}_{2} \mathrm{O}$ were dissolved in $10 \mathrm{ml}$ deionized water. A $1 \mathrm{M} \mathrm{NaOH}$ solution was dropwise added until a $\mathrm{pH}$ value of 3 was reached. The appropriate $\mathrm{pH}$ value of the reaction solution is essential for the formation of compound 2. The following procedure helps to find the required reaction parameters. After the phosphonoacetic acid and the copper salt were dissolved in water a $1 \mathrm{M} \mathrm{NaOH}$ solution was added until a permanent precipitate is formed. Afterwards the precipitate was dissolved by adding $0.05 \mathrm{M} \mathrm{HNO}_{3}$ dropwise. By adding of $95 \mathrm{mg}$ urea blue crystals appeared after several days at room temperature.

IR (ATR): 1: $3329(\mathrm{~m}), 3327(\mathrm{~m}), 3119(\mathrm{w}), 1543(\mathrm{~m}), 1413(\mathrm{~m}), 1392(\mathrm{~m})$, $1272(\mathrm{~m}), 1239(\mathrm{~m}), 1151(\mathrm{~s}), 1062(\mathrm{~s}), 932(\mathrm{~m}), 850(\mathrm{~m}), 732(\mathrm{w}), 655$ $(\mathrm{w}, \mathrm{sh}), 620(\mathrm{~s}), 542(\mathrm{~s}), 480(\mathrm{~m}), 421(\mathrm{~s}), 397(\mathrm{~m}, \mathrm{sh}), 332(\mathrm{~m}) \mathrm{cm}^{-1}$. 2: 3500-3000 (s,broad), 2937 (w), 1558 (s), 1426 (s), 1393 (s), 1205 (s), $1126(\mathrm{~s}), 1070(\mathrm{~m}), 1034(\mathrm{~s}), 979(\mathrm{~m}), 957(\mathrm{~m}), 816(\mathrm{~m}), 758(\mathrm{~m}), 642(\mathrm{~m})$, $530(\mathrm{~m}), 497(\mathrm{w}), 446(\mathrm{~m}), 349(\mathrm{~m}) \mathrm{cm}^{-1}$.

ATR Fourier transformed infrared (IR-ATR) measurements were carried out at room temperature with a resolution of $2 \mathrm{~cm}^{-1}$ using a Bruker Alpha FT-IR spectrometer equipped with diamond ATR unit. Thermoanalytic measurements with a heating rate of $10 \mathrm{~K} \mathrm{~min}^{-1}$ were performed in flowing air using a Netzsch STA 449 device. Temperature dependent magnetizations were measured at $\mu_{0} \mathrm{H}=0.3 \mathrm{~T}$ in the temperature range of 3 to $300 \mathrm{~K}$ using a Quantum Design PPMS 9. The magnetic data were corrected against the diamagnetic moment of the sample holder. The Xray powder diffraction pattern was recorded at room temperature on a Bruker D8-Advance diffractometer, equipped with a one-dimensional silicon strip detector (LynxEye ${ }^{\mathrm{TM}}$ ) and operated with Cu-Ka radiation. The diffuse reflectance UV-Vis spectrum was obtained using a Perkin Elmer UV/Vis spectrometer Lambda 19. $\mathrm{BaSO}_{4}$ was used as a white standard. $\mathrm{X}$-ray single crystal structure determination was performed on a Siemens P4 four-circle diffractometer (MoKo, graphite monochromator) in a theta range up to $24.00^{\circ}$ and $28.00^{\circ}$, respectively. Face-indexed numerical absorption corrections have been applied. The phase problem was solved by direct methods. Full matrix least squares refinement employing $|F|^{2}$ made use of the SHELXTL program suite. ${ }^{[60]}$ The $C$ bound hydrogen atoms were positioned geometrically. The further hydrogen atom positions were located in Difference Fourier maps and refined with isotropic displacement parameters. An empirical extinction coefficient was used with (2). Crystallographic data are compiled in Table 7. Further crystallographic data have been deposited with the Cambridge Crystallographic Data Centre, CCDC, 12 Union Road, Cambridge CB21EZ, UK. Copies of the data can be obtained free of charge on quoting the depository number CCDC-1518841 (1) and 1518854 (2) (Fax: +44-1223-336-033; E-Mail: deposit@ccdc.cam.ac.uk, http://www.ccdc.cam.ac.uk).

Table 7. Crystallographic Data

\begin{tabular}{|c|c|c|}
\hline Compound & 1 & 2 \\
\hline Empirical formula & $\mathrm{C}_{2} \mathrm{H}_{7} \mathrm{PCuO}_{7}$ & $\mathrm{C}_{2} \mathrm{H}_{12} \mathrm{PCu}_{1.5} \mathrm{O}_{10}$ \\
\hline Crystal system & Monoclinic & Triclinic \\
\hline Space group & C2/c (no.15) & $P \overline{1}$ (no. 2) \\
\hline Lattice constants & $\begin{array}{l}\mathrm{a}=1623.3(2) \mathrm{pm} \\
\mathrm{b}=624.0(1) \mathrm{pm} \\
c=1495.5(2) \mathrm{pm} \\
\beta=122.45(1)^{\circ}\end{array}$ & $\begin{array}{l}\mathrm{a}=608.2(1) \mathrm{pm} \\
\mathrm{b}=800.1(1) \mathrm{pm} \\
c=1083.6(1) \mathrm{pm} \\
\alpha=94.98(1)^{\circ} \\
\beta=105.71(1)^{\circ} \\
\gamma=109.84(1)^{\circ}\end{array}$ \\
\hline
\end{tabular}




\begin{tabular}{|c|c|c|}
\hline Cell volume & $1.2783(3) \mathrm{nm}^{3}$ & $0.46808(3) \mathrm{nm}^{3}$ \\
\hline Formulas in unit cell & 8 & 2 \\
\hline Formula weight & $237.59 \mathrm{~g} \mathrm{~mol}^{-1}$ & $322.40 \mathrm{~g} \mathrm{~mol}^{-1}$ \\
\hline Density (calc.) & $2.469 \mathrm{~g} \mathrm{~cm}^{-3}$ & $2.287 \mathrm{~g} \mathrm{~cm}^{-3}$ \\
\hline Wavelength & \multicolumn{2}{|c|}{$71.073 \mathrm{pm}$} \\
\hline Absorption coefficient & $3.658 \mathrm{~mm}^{-1}$ & $3.647 \mathrm{~mm}^{-1}$ \\
\hline Numerical absorption correction & $\begin{array}{l}\min . / \max . \\
\text { transmittance } \\
0.6486 / 0.9306\end{array}$ & $\begin{array}{l}\min . / \max . \\
\text { transmittance } \\
0.7160 / 0.8455\end{array}$ \\
\hline Temperature & \multicolumn{2}{|c|}{$293(2) \mathrm{K}$} \\
\hline Crystal size (mm) & $0.22 \times 0.08 \times 0.02$ & $0.04 \times 0.12 \times 0.10$ \\
\hline$F(000)$ & 952 & 325 \\
\hline$\Theta$-range & $2.97^{\circ}-24.00^{\circ}$ & $2.76^{\circ}-28.00^{\circ}$ \\
\hline Limiting indices & $\begin{array}{l}\text { h: }-18 /+18 ; \mathrm{k}:-7 /+7 \\
\mathrm{l}:-17 /+17\end{array}$ & $\begin{array}{l}\mathrm{h}:-1 /+8 ; \mathrm{k}:-10 /+10 \\
\mathrm{l}:-14 /+14\end{array}$ \\
\hline Reflections collected & 2070 & 3486 \\
\hline Independent reflections & $1004\left(R_{\text {int }}=0.0349\right)$ & $2249\left(R_{\text {int }}=0.0327\right)$ \\
\hline Structure solution & \multicolumn{2}{|c|}{ Direct methods } \\
\hline Structure refinement & \multicolumn{2}{|c|}{ Full-matrix least-squares on $|\mathrm{F}|^{2}$} \\
\hline Refined parameters & 118 & 166 \\
\hline Extinction coefficient & & $0.0040(5)$ \\
\hline Final max. shift/esd & $-0.059(\mathrm{H}(22))$ & $0.008(H(42))$ \\
\hline Final mean shift/esd & 0.006 & 0.001 \\
\hline Goodness-of-fit on $|\mathrm{F}|^{2}$ & 1.412 & 1.143 \\
\hline Residuals (all data) & $\begin{array}{l}\mathrm{R}_{1}=0.0377, w \mathrm{R}_{2}= \\
0.0763\end{array}$ & $\begin{array}{l}\mathrm{R}_{1}=0.0451, w R_{2}= \\
0.0565\end{array}$ \\
\hline $\begin{array}{l}\text { Max. features in last Difference } \\
\text { Fourier synthesis }\end{array}$ & $\begin{array}{l}575 \text { and }-639 \\
\text { e. } \mathrm{nm}^{-3}\end{array}$ & $\begin{array}{l}440 \text { and }-396 \\
e \cdot n m^{-3}\end{array}$ \\
\hline
\end{tabular}

\section{Acknowledgements}

One of the authors (R.K.) is thankful to the German Research Foundation (DFG) within the Collaborative Research Centre (SFB 762) Functionality of Oxide Interfaces for financial support.

Keywords: Phosphonoacetic acid • UV-Vis spectroscopy • coordination polymer $\bullet$ Crystal structure $\bullet$ Magnetic properties

\section{References}

[1] L.C. Brousseau III and T.E. Mallouk, Anal. Chem. 1997, 69, 679-687.

[2] H. Byrd, A. Clearfield, D. Poojary, K.P. Reis, M.E. Thompson, Chem. Mater. 1996, 8, 2239-2246.

[3] M.E. Thompson, Chem. Mater. 1994, 16, 1168-1175.

[4] C.-Y. Yang and A. Clearfield, React. Polym. 1987, 5, 13-21.

[5] G. Albert, U. Costantino, F. Marmottini, R. Vivani, P. Zappelli, Angew. Chem. Int. Ed. Engl. 1993, 32, 1357-1359.

[6] D. Riou and G. Férey, J. Mater. Chem. 1998, 8, 2733-2735.

[7] R. Köferstein, M. Arnold, C. Robl, Z. Anorg. Allg. Chem. 2016, 642, 1126-1132.

[8] J.-T. Li and L.-M. Zheng, Inorg. Chim. Acta 2009, 362, 1739-1742.

[9] J.-J. Wang, L.-P. Zhang, L. Huang, J. Chen, J. Coord. Chem. 2012, 65, 3274-3286.

[10] A. N. Alsobrook and T. E. Albrecht-Schmitt, Inorg. Chem. 2009, 48 11079-11084

[11] A. Cabeza, M. A. G. Aranda, S. Bruque, J. Mater. Chem. 1998, 8, 2479-2485.

[12] M. Sanselme, M. Riou-Cavellec, J.-M. Grenéche, G. Férey, J. Solid State Chem. 2002, 164, 354-360.

[13] G. B. Hix, D. S. Wragg, P. A. Wright, R. E. Morris, J. Chem. Soc. Dalton Trans. 1998, 3359-3361.

[14] G. B. Hix, A. Turner, B. M. Kariuki, M. Tremayne, E. J. MacLean, J. Mater. Chem. 2002, 12, 3220-3227.

[15] M. Deng, Y. Ling, B. Xia, Z. Chen, Y. Zhou, X. Liu, B. Yue, H. He, Chem. Eur. J. 2011, 17, 10323-10328.

[16] T.-B. Liao, Y. Ling, Z.-X. Chen, Y.-M. Zhou, L.-H. Weng, Chem. Comm. 2010, 46, 1100-1102

[17] A. N. Alsobrook, B. G. Hauser, J. T. Hupp, E. V. Alekseev, W. Depmeier, T. E. Albrecht-Schmitt., Chem. Comm. 2010, 46, 9167-9169.

[18] T. Lis, Acta Cryst. 1997, C53, 28-42.

[19] K. Slepokura, A. Piatkowska, T. Lis, Z. Kristallogr. 2002, 217, 614-621.

[20] K. E. Knope and C. L. Cahill, Inorg. Chem. 2008, 47, 7660-7672.

[21] F. A. Mautner, M. S. El Fallah, O. Roubeau, S. Speed, S. J. Teat, R. Vicente, Eur. J. Inorg. Chem. 2013, 3483-3490.

[22] N. Stock, S. A. Frey, G. D. Stucky, A. K. Cheetham, J. Chem. Soc., Dalton Trans. 2000, 4292-4296.

[23] J. C. Tan, C. A. Merrill, J. B. Orton, A. K. Cheetham, Acta Mater. 2009 57, 3481-3496.

[24] S. Lodhia, A. Turner, M. Papadaki, K. D. Demadis, G. B. Hix, Cryst. Growth Des. 2009, 9, 1811-1822.

[25] B.J. Hathaway, in Comprehensive Coordination Chemistry, (Ed. G. Wilkinson) Pergamon Press, Oxford 1985, vol. 5, p. 533-774.

[26] B.J. Hathaway and D.E. Billing, Coord. Chem. Rev. 1970, 5, 143-207.

[27] A. Pasquarello, I. Petri, P.S. Salmon, O. Parisel, R. Car, E. Tóth, D. H. Powell, H. E. Fischer, L. Helm, A. E. Merbach, Science 2001, 291 856-859.

[28] T. D. Keene, I. Zimmermann, A. Neels, O. Sereda, J. Hauser, S.-X. Liu, S. Decurtins, Cryst. Growth Des. 2010, 10, 1854-1859.

[29] F. S. Stephens, J. Chem. Soc. A, 1969, 2493-2501.

[30] N. Ito, S. E. V. Phillips, C. Stevens, Z. B. Ogel, M. J. McPherson, J. N. Kneen, K. D. S. Yadav, P. F. Knowles, Nature 1991, 350, 87-90.

[31] T.G. Fawcett, M. Ushay, J. P. Rose, R. A. Lalancette, J. A. Potenza, H. J. Schugar, Inorg. Chem. 1979, 18, 327-332.

[32] P. R. Levstein and R. Calvo, Inorg. Chem. 1990, 29, 1581-1583.

[33] N. E. Brese and M. O'Keeffe, Acta Cryst. 1991, B47, 192-197.

[34] A. Weiss, Chem. Ber. 1958, 91, 487-502.

[35] C. Robl and S. Hentschel, Mater. Res. Bull. 1991, 26, 1335-1362

[36] A. Tahli, Ü. Köc, R.F.M. Elshaarawy, A.C. Kautz, C. Janiak, Crystals 2016, 6, 23

[37] D. C. Luehrs, B. C. Cornilsen, C. B. Glover, T. L. Neils, Inorg. Chim. Acta 1988, 145, 81-84.

[38] G. B. Deacon and R. J. Philips, Coord. Chem. Rev. 1980, 33, 227-250.

[39] K. Moedritzer and R. R. Irani, J. Inorg. Nucl. Chem. 1961, 22, 297-304. 
[40] A. W. Herlinger, J. R. Ferraro, J. A. Garcia, R. Chiarizia, Polyhedron 1998, 17, 1471-1475.

[41] K.-R. Ma, C.-Li. Wei, Y. Zhang, Y.-H. Kan, M.-H. Cong, X.-J. Yang, J. Spectros. 2013, 378379.

[42] G. S. Manku, Theoretical Principles in Inorganic Chemistry, Tata McGraw-Hill Publishing Company, New Dehli, 2006. p. 532 et seq.

[43] B. N. Figgis and J. Lewis, Prog. Inorg. Chem. 1964, 6, 237-239.

[44] R. Köferstein and C. Robl, Z. Anorg. Allg. Chem. 2015, 641, 1886-1891.

[45] D. Mastropaolo, D. A. Powers, J. A. Potenza, H. J. Schugar, Inorg. Chem. 1976, 15, 1444-1449.

[46] V. H. Crawford, H. W. Richardson, J. R. Wasson, D. J. Hodgons, W. E. Hatfield, Inorg. Chem. 1976, 15, 2107-2110.

[47] L. Merz and W. Haase, J. Chem. Soc. Dalton Trans. 1980, 875-879.

[48] H.-J. Koo, D. Dai, M.-H. Whangbo, Inorg Chem. 2005, 44, 4359-4365.

[49] K. Nawa, T. Yajimi, Y. Okamoto, Z. Hiroi, Inorg. Chem. 2015, 54, 5566-5570.

[50] H.-J. Koo and M.-H. Whanbo, Inorg. Chem. 2001, 40, 2161-2169.

[51] A. A. Belik, M. Azuma, A. Matsuo, M.-H. Whangbo, H.-J. Koo, J. Kikuchi, T. Kaji, S. Okubo, H. Ohta, K. Kindo, M. Takano, Inorg. Chem. 2005, 44, 6632-6640.
[52] K. Bathelet, M. Nogues, D. Riou, G. Férey, Chem. Mater. 2002, 14, 4910-4918.

[53] F. A. Mautner, M. Salah El Fallah, S. Speed, R. Vicente, Polyhedron 2014, 81, 1-5.

[54] H. Zhu, J. Huang, S.-S. Bao, M. Ren, L.-M. Zheng, CrystEngComm.. 2013, 15, 10316-10322.

[55] J. Huang, P.-Y. Liu, H. Zhu, S.-S. Bao, L.-M. Zheng, J. Ma, ChemPlusChem 2012, 77, 1087-1095.

[56] A. A. G. Tomlinson and B. J. Hathaway, J. Chem. Soc. (A) 1968, 1905-1909.

[57] P. Sreeramulu, K. M. Sundar Jacob, B. J. Reddy, J. Crystallogr. Spectrosc. Res. 1990, 20, 93-96.

[58] K. M. Reddy, A. S. Jacob, B. J. Reddy, Y. P. Reddy, phys. stat. sol. (b) 1987, 139, K145-K150.

[59] M. Arnold, Dissertation, Universität Jena, Germany, 1998.

[60] G. M. Sheldrick, Acta Cryst. 2008, A64, 112-122.

Received: ((will be filled in by the editorial staff))

Published online: ((will be filled in by the editorial staff)) 